Article

\title{
Conceptual and Operational Integration of Governance, Financing, and Business Models for Urban Nature-Based Solutions
}

\author{
Aitziber Egusquiza ${ }^{1, *}$, Maider Arana-Bollar ${ }^{1}$, Amaia Sopelana ${ }^{1}\left(\mathbb{D}\right.$ and Javier Babí Almenar ${ }^{2}$ \\ 1 TECNALIA, Basque Research and Technology Alliance (BRTA), Parque Científico y Tecnológico de Bizkaia, \\ Astondo Bidea, Edificio 700, E-48160 Derio, Spain; maider.arana@tecnalia.com (M.A.-B.); \\ amaia.sopelana@tecnalia.com (A.S.) \\ 2 RDI Unit on Environmental Sustainability Assessment and Circularity, Environmental \\ Research \& Innovation (ERIN) Department, Luxembourg Institute of Science and Technology (LIST)—41 Rue \\ du Brill, L-4422 Belvaux, Luxembourg; javier.babialmenar@list.lu \\ * Correspondence: aitziber.egusquiza@tecnalia.com; Tel.: +34-667-178-981
}

Citation: Egusquiza, A.; Arana-Bollar, M.; Sopelana, A.; Babí Almenar, J. Conceptual and Operational Integration of Governance, Financing, and Business Models for Urban Nature-Based Solutions. Sustainability 2021, 13 , 11931. https://doi.org/10.3390/ su132111931

Academic Editors: Alessandro Pagano, Elena López Gunn, Leon Kapetas and Beatriz Mayor

Received: 20 September 2021

Accepted: 22 October 2021

Published: 28 October 2021

Publisher's Note: MDPI stays neutral with regard to jurisdictional claims in published maps and institutional affiliations.

Copyright: (c) 2021 by the authors. Licensee MDPI, Basel, Switzerland. This article is an open access article distributed under the terms and conditions of the Creative Commons Attribution (CC BY) license (https:// creativecommons.org/licenses/by/ $4.0 /)$.

\begin{abstract}
Governance, financing, and business models are deeply interlinked and relevant for the successful implementation of urban nature-based solutions (NBS). However, during the definition of urban NBS projects the importance and interrelation of these models are usually neglected. To overcome this limitation, this paper presents an overarching framework (conceptual and operational) and a derived preselection web tool which interrelate governance, financing, and business models for NBS projects. First, based on recent literature, governance, financing, and business models that could be applied to NBS were mapped, and their integration proposed. Later, key contextual factors influencing NBS implementation were identified. They form the basis of a WHAT-WHO-HOW framework that structures the links between specific NBS projects, their implementation context, and the most suitable models. From that framework, and an analysis of 50 successful NBS case studies, a suitability matrix was developed with known models. The matrix allows pairing types of NBS and their initiating actors with suitable financing and governance models. Lastly, a tailored NBS business model canvas was designed to evaluate the business model components. From the overarching framework, the preselection web tool was created to guide decision-making on suitable governance, finance, and business models in the early phases of NBS projects.
\end{abstract}

Keywords: nature-based solutions; implementation models; governance; financing; business models; urban areas

\section{Introduction}

Nature-based solutions (NBS) are gaining traction as a novel umbrella concept that represents solutions inspired by and composed of nature, offering an alternative to traditional grey solutions. NBS are considered multifunctional and cost-effective solutions that are capable of addressing societal challenges [1-3], for example in providing strategies for the mitigation of natural hazards [4-6]. However, compared to traditional grey solutions, conceptual uncertainties (e.g., return of investment) still arise around NBS projects, hampering their acceptance among decision-makers and private stakeholders [7]. Besides conceptual uncertainty, the reluctance of the general to accept NBS initiatives also stems from a lack of legitimate participation processes during their planning and design [8,9]. Moreover, a disconnection between short-lived political cycles and long-term urban challenges blurs responsibilities and poses challenges (e.g., financial) to the establishment of continuous maintenance programs for urban NBS [10]. NBS implementation may also be hampered by governance issues such as the rigidity of municipal structures and their legal frameworks [11], as well as a lack of coordination between departments [12-14]. Consequently, during the definition of urban planning actions at the local level (as well as specific urban 
interventions), conceptual uncertainties, in addition to the rigidness coming from local governments, generate implementation barriers that could impede the consideration of NBS as suitable solutions or reduce their success.

Urban planning actions such as urban greening strategies usually involve five phases, i.e., preparatory/exploratory, feasibility/conceptual, formal planning, design/implementation, and operational or post-implementation. Similarly, urban interventions or projects, e.g., the regeneration of a public square, tend to be structured in seven phases, i.e., strategic definition, preparatory briefing, conceptual design, spatial coordination, technical design, construction, and operational (see RIBA Plan of Work [15] for further details). In both cases, it is during the first three phases when conceptual uncertainties around urban NBS need to be resolved and suitable governance, financing, and business models for them need to start being defined to overcome or minimize implementation barriers.

In part, the conceptual uncertainties of NBS are associated with their innovative nature and novel governance and business models [16] which do not always match those of grey solutions. For the definition of strategic or specific urban NBS projects, especially during the preparatory and conceptual phases, several authors state the need to analyse key stakeholders (social actors), the suitability of governance arrangements, and funding and business models $[17,18]$. Qiao et al. also emphasize that an informed implementation of urban NBS requires an analysis of the rules that govern the interactions among social actors and available resources [19]. This analysis should occur in early planning phases. Furthermore, to increase the acceptance and success of NBS projects in the postimplementation phases, it is crucial to adapt them to the local socio-ecological context where they will be implemented [16,20,21]. For this adaptation, it is necessary to consider key contextual factors in the preparatory and conceptual phases of urban NBS projects or action plans including them. Despite the importance of the above aspects to overcome NBS implementation barriers, institutions supporting urban NBS mainstreaming, e.g., the European Commission [22] via initiatives such as H2020 projects, still tend to disregard them in the definition of frameworks and decision support tools for NBS.

Despite the above limitations, decision-makers and initiating actors of NBS projects are starting to demand user-friendly tools that offer guidance at least for the selection of suitable business models for NBS. The definition of business models is usually considered the first step for developing a strong business case [23]. However, the societal benefits stemming from NBS implementation (e.g., enhanced urban cooling) are not always easy to capture or link to a return on investments $[16,24]$. The monetary value of NBS and their business potential are highly dependent on their social value, the preferences of the different stakeholders, and the specific socio-political context where they are implemented $[16,25]$. The cost-effectiveness and feasibility of NBS projects are also determined by their long-term management (occurring in the post-implementation phase), which is linked to governance models decided in the pre-implementation phases. Consequently, the specific combination of governance, business, and financing models used to plan, develop, and manage a particular NBS directly influences its performance [26]. Therefore, a more effective NBS implementation process would benefit from an integrated consideration of collective action arrangements between stakeholders (governance model) and the associated financing and business models, including market-shaping strategies (MSSs), which are opportune for lessening the uncertainties associated with new markets [27].

The aim of this paper is twofold: (i) to present the development of an overarching NBS implementation framework that considers governance, financing, and business models in an integrated way; (ii) to present a preselection web tool of NBS implementation models developed based on the previous overarching framework. The overarching framework was developed at a conceptual level and an operational level. For the conceptual level, key literature on governance, financing, and business models was reviewed. The operational level was supported by the empirical assessment of cases studies of successful urban NBS projects that had already been implemented, which acted as "real-life" grounding examples guiding the suitable combination of models. As a practical value for decision-makers, the 
preselection tool could help to mitigate the abovementioned implementation barriers and overcome the limitations of current decision support tools for urban NBS.

Regarding the socio-economic and geographic scope, this research is focused on European urban contexts, and therefore the framework and preselection tool were developed to be suitable in those contexts. In this sense, it is important to clarify that this paper understands "urban contexts" as any type of city, town, peri-urban or suburban area, or small thinly-population settlement, as has recently been recommended by the United Nations [28]. Consequently, urban NBS projects might involve interventions that span along a municipality or cross several, or which are limited to an urban block or groups of them, and might co-involve local to regional governance levels. It is also relevant to clarify that the development of a global framework and decision support suitable for any context is beyond the scope of this research, may not have been feasible (e.g., due to core planning system differences), and would have required an in-depth understanding of many other planning and governance systems. Additionally, as emphasized in the previous paragraphs, the early phases of urban planning actions and specific urban projects are the critical phases when governance, financing, and business models should be defined. Hence, the framework and online preselection tool presented here were developed to be useful at those stages when information is not complete, mainly qualitative and tools should be simple enough to be integrated in current workflows.

The following section describes the seven methodological steps carried out for the integration of governance, financing, and business models at the conceptual and operational levels, including the development of the online implementation model preselection tool. From the next section, the term "implementation model" (IM) is used only when referring to the integration of governance, financing, and business models. The term "governance" refers to collective action arrangements designed in order to implement NBS projects, while the term "government" refers to the formal organisations of the "public sector" [29]. Section 3 presents key results regarding (i) the map of governance, finance, and business models as well as their integration; (ii) the advantages and limitations of different integrations of implementation models; and (iii) the canvas defined for the implementation model preselection tool. In the last section, the advantages and disadvantages of the current work are summarised and future outlooks are briefly outlined. Section 4 is devoted to discussion and main conclusions are featured.

\section{Methodology}

The methodological approach utilised to undertake the integration of governance, financing, and business models for NBS projects covers 7 steps, as shown in Figure 1. The 7 steps aim to develop the abovementioned overarching NBS implementation framework covering the conceptual level (through key literature) and the operational level (through the empirical assessment of cases studies) in the 3 dimensions (governance, financing, and business models):

1. Mapping and clustering of governance, financing, and business models from key literature.

2. Definition of an integrated model (IM) typology that clusters governance, finance, and business models based on the degree of involvement of different types of social actors.

3. Identification of implementation factors linked to a particular socio-ecological system.

4. Definition of the WHAT-WHO-HOW framework (WHAT: NBS project, WHO: initiating actors, HOW: the implementation model) that interrelate the key contextual factors.

5. Development of the suitability matrix that builds on the previous steps and an analysis of 50 real NBS case studies (see Table A1 in Appendix A or the database in [30]). It matches NBS projects with suitable IMs, considering the initiating actor of the project and contextual factors (e.g., ownership, scale) using the WHAT-WHO-HOW framework.

6. Building of the NBS business case by assessing how suitable the sustainable business model (SBM) classified by Lüdeke-Freund et al. [31] is for NBS projects. The NBSoriented business model canvas (BSM) of [32] was selected as a suitable tool to integrate and visualise the results. 
7. Creation of the IM preselection tool.

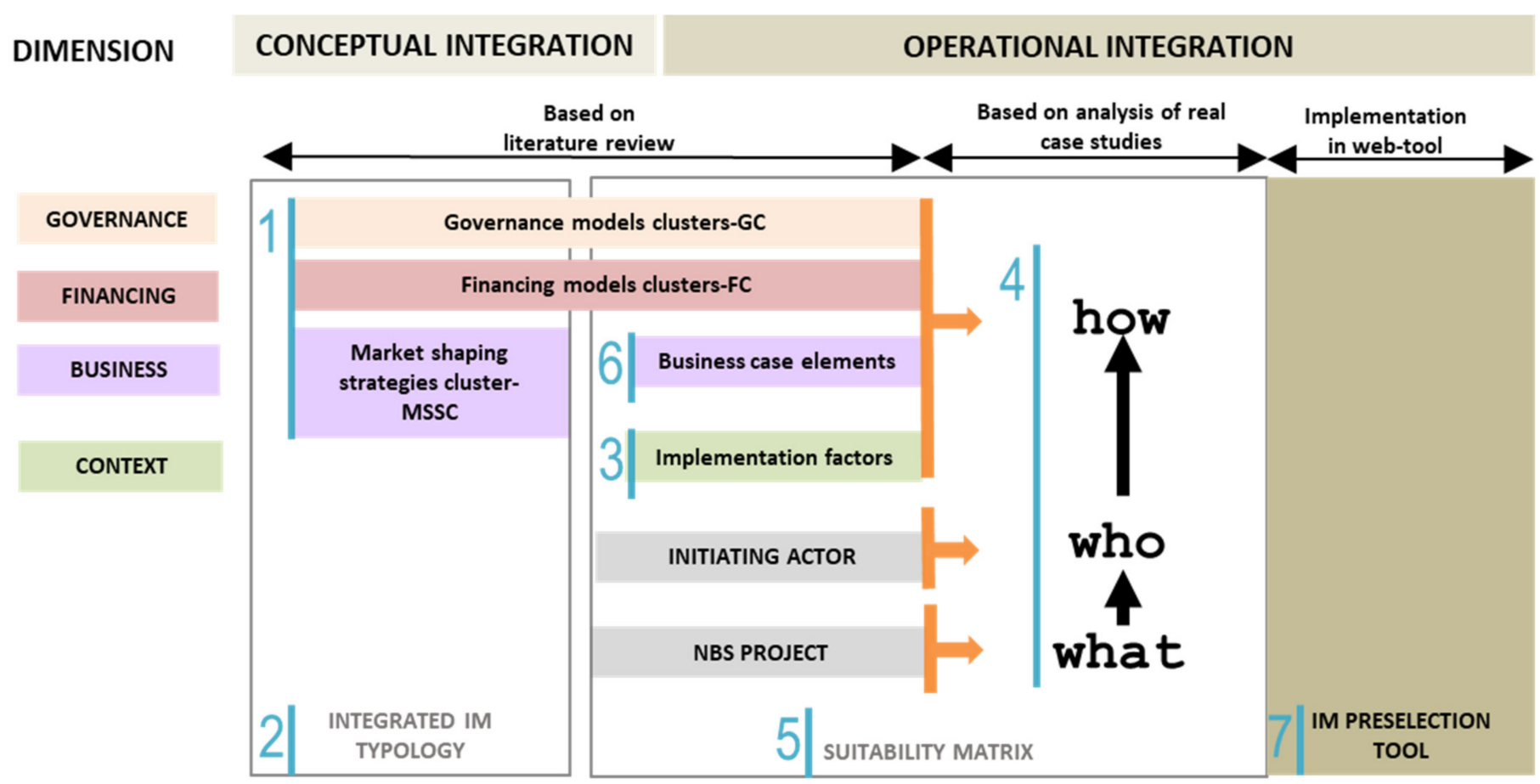

Figure 1. The 7 methodological steps for the conceptual and operational integration.

Steps 1 and 2 correspond to the conceptual side; meanwhile, Steps 3 to 6 represent its operationalisation (practical character) to support the implementation of real NBS projects. The following subsections describe in detail each of the steps.

\subsection{Conceptual Integration}

Conceptual integration is explored to endow operational integration with a robust framework based on current theoretical perspectives in the field. It also provides a reflection on integrated strategies of governance, financing, and business models and their implication in terms of NBS project implementation.

2.1.1. Step 1: Mapping and Clustering of Governance Models, Financing Schemes, and Business Models

Urban and environmental governance arrangements were analysed to identify and map them. Both are relevant since urban NBS projects or action plans integrating them require models that are at the intersection of urban and environmental governance.

For mapping purposes, urban governance is understood with its double meaning, described by Moretto as [33]: (i) "the formal, institutional theoretical and normative side" and (ii) the side that is "informal, local, community-based beyond policies and strategies". Similarly, for mapping, environmental governance is considered as presented by Chaffin et al. [34] as a system composed of public institutions and private organizations that define a set of legal and social norms and regulations to govern environmental resource use and protection. To better understand current environmental governance models, the literature review conducted by Lemos and Agrawal was used as a basis [35].

In terms of financing models, depending on the governance model, urban NBS type (e.g., urban forest, green roofs), size, and scope, the NBS project can be funded through diverse financing models. The options can range from informal, grassroots, citizen-led fundraising to structured multi-national cooperation plans managed by development financing institutions. Both conventional and non-conventional funding methods to pay 
for NBS implementation were mapped using as a basis the funding methods reviewed in the $\mathrm{N} 4 \mathrm{C}$ project [36].

The urban and environmental financing and governance models found in literature could not be structured in clearly delimited boxes since conceptually models overlap regarding some characteristics. The triangle formed by state/government, market, and community (governance and financing triangle) can be used as the framework to schematically structure and classify strategies for environmental governance and financing strategies [35]. This triangle is formed by 3 axes (i.e., government-community, government-market, and community-market) that connect the above 3 attributes (Figure 2).

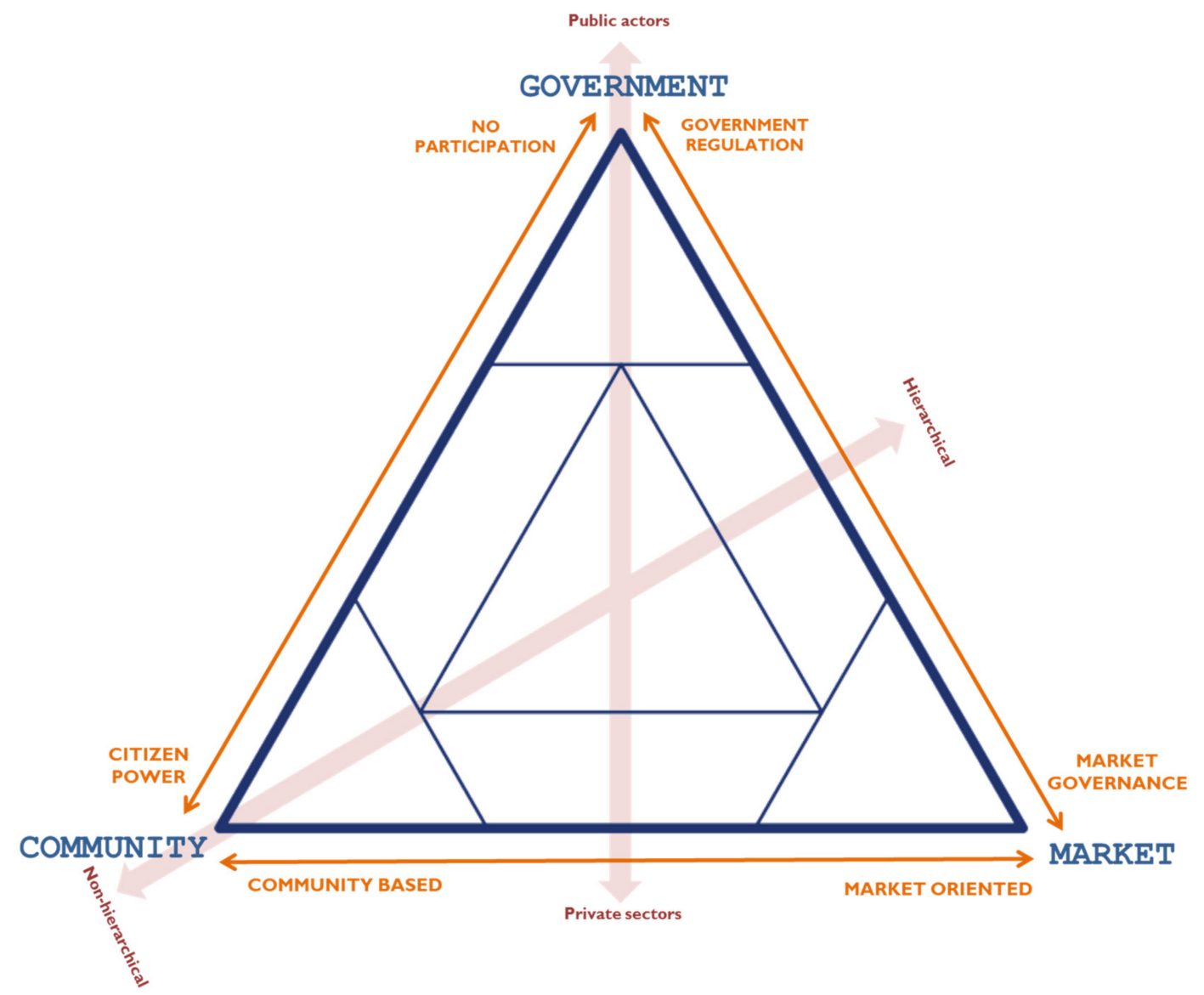

Figure 2. Mapping governance, business, and financing models in a 3-axis scheme to facilitate its posterior integration.

Based on the work of Abbot and Snidal, the "governance and financing triangle" is divided into 7 different zones which were used to map different types of governance and financing arrangements [37]. During the operational integration, the triangle also facilitates the identification of suitable implementation models according to the initiating actor (WHO).

The gradients in urban governance are well represented as the Government-Community axis. In 1969, Arnstein proposed that the degree of involvement of the citizen in planning processes could be placed at different degrees ranging from no participation to citizen control [38]. Governance decisions could range from an approach where the government aims to achieve public support for already-made decisions to a situation where the public has the power to assure accountability or even to plan and manage without intermediaries. To better understand at which point on this axis a model is placed, the intensity of participation can be classified according to the range of parties included in the decision-making 
process, the intensity and direction of information flow, and the level of influence in the decisions to be made [39].

The environmental governance side can be represented as the Government-Market axis. Here, the involvement of market actors in environmental collaboration helps to overcome the inefficiencies of government action by injecting competitive pressures through market actors capable of achieving bigger profitability in the utilization of environmental resources [35]. In a competitive context, self-interested individuals express their desires as consumers in a specific market. The different models for this kind of arrangement could be placed on a spectrum that ranges from almost fully public-sector governance (government regulation) to almost fully private-sector governance (market governance) through a mixed model with different degrees of private involvement: solely agreeing on the framework of the project, creating joint ventures with equal participation of private and government, or taking authority over what to do and how to do it, making efforts to include the broader community.

The Community-Market axis represents the cases in which the governance and financing arrangements occur between private actors in a non-hierarchical mode. In other words, this axis becomes more relevant for decisions led by citizens, with minimum intervention of public government or by private organizations that act as market actors or balance between both.

Concerning business models, conceptual mapping focuses specifically on sustainable business models (SBMs) as considered by Geissdoerfer [40]. This means that models either incorporate concepts, principles, or goals that aim at sustainability or integrate sustainability into their value proposition, value creation and delivery activities, and/or value capture mechanisms. In the specific case of NBS, which need to fulfil the provision of social, economic, and environmental benefits cost-effectively [22], it was considered necessary to narrow down conceptual business models to those that consider sustainability criteria. As part of the review of business models, a study mapping SBMs by proposing archetypes was considered as a potential reference [41]. However, in that study SBM archetypes were not defined with enough detail to be mapped, and a posteriori, it could not have been used to build conceptual integrated implementation models. As an alternative, literature on market-shaping strategies $[27,42]$ was found to be more adequate for the initial mapping of SBMs and their posterior integration as part of implementation models.

The identification of potential business models for novel solutions such as NBS projects which differ from governance and financing models requires a case-by-case approach. However, due to the uncertainties associated with NBS (as anticipated in Section 1), there is still a commercial reluctance from the business side. In fact, private sector participation in NBS projects is still incipient [30]. Market-shaping strategies (MSSs) have already been identified as appropriate to mitigate uncertainties associated with new markets [27], justifying their use. Specifically, Knight et al. identified collaborative relationships, long-term contracts, and the use of intermediaries as market-taking strategies to mitigate supply uncertainty in new markets, and considered possible implications for market evolution and dynamics [27]. Pro-active shaping strategies are also useful where the institutional framework is insufficiently supportive and the regulatory framework and cultural-cognitive aspects are highly rigid [42], which is the case of NBS projects, as already reported in Section 1. Therefore, the use of market-shaping strategies could serve as a tool for use in combination with the triangle formed by the 3 types of initiating actors (i.e., public institutions, private businesses, citizen community). Mapping of MSS could be also overlapped on the triangle, and it would facilitate the inclusion of the private sector in the implementation of NBS through the shaping of the emergent market. Two main literature sources were used to identify the MSS, and their application to NBS projects was assessed as can be seen in Table 1. 
Table 1. Market shaping strategies (MSSs) and their application to NBS projects ( $\mathrm{P}=$ primary source; $\mathrm{S}=$ secondary source).

\begin{tabular}{|c|c|c|c|c|}
\hline \multirow{2}{*}{ TARGET } & \multirow{2}{*}{ MSS } & \multicolumn{2}{|c|}{ SOURCE } & \multirow{2}{*}{ NBS APPLICATION } \\
\hline & & $\mathbf{P}$ & $\mathbf{S}$ & \\
\hline \multicolumn{5}{|c|}{$\begin{array}{l}\text { CLUSTER 1: PRIVATE MSS } \\
\text { Initiating actor: MARKET * }\end{array}$} \\
\hline \multirow{4}{*}{ Community } & $\begin{array}{l}\text { Obtaining knowledge } \\
\text { about user behaviour }\end{array}$ & [43] & [44] & $\begin{array}{l}\text { Using the obtained knowledge for NBS-oriented } \\
\text { product development }\end{array}$ \\
\hline & $\begin{array}{l}\text { Shaping the preferences } \\
\text { of the end-users }\end{array}$ & [43] & {$[27,44,45]$} & $\begin{array}{l}\text { Promoting NBS through collaborative marketing and } \\
\text { direct relationships with citizens }\end{array}$ \\
\hline & $\begin{array}{l}\text { Reframing the } \\
\text { discourse }\end{array}$ & [43] & [46] & $\begin{array}{l}\text { Building a new discourse around social and } \\
\text { ecological values of NBS instead of monetary ones }\end{array}$ \\
\hline & $\begin{array}{l}\text { Building demand for } \\
\text { sustainable innovation }\end{array}$ & [43] & [47-49] & $\begin{array}{l}\text { Integrating the principles of open innovation } \\
\text { co-creation along the value chain for NBS projects }\end{array}$ \\
\hline \multirow[t]{2}{*}{ Market } & $\begin{array}{l}\text { Boundary spanning } \\
\text { within and beyond } \\
\text { the firm }\end{array}$ & [43] & {$[50]$} & \multirow{2}{*}{$\begin{array}{c}\text { Strategic partnerships among private actors can } \\
\text { develop in business ecosystems, improving the } \\
\text { suitability for NBS projects }\end{array}$} \\
\hline & $\begin{array}{l}\text { Buyer-buyer } \\
\text { cooperation }\end{array}$ & [43] & [27] & \\
\hline Government & $\begin{array}{l}\text { Influencing the } \\
\text { regulatory institutions }\end{array}$ & [43] & {$[45,51]$} & $\begin{array}{l}\text { Exemplary NBS projects could help to gain visibility } \\
\text { and increase the awareness and legitimisation of } \\
\text { citizens and public bodies }\end{array}$ \\
\hline
\end{tabular}

CLUSTER 2: PUBLIC MSS

Initiating actor: GOVERNMENT *

\begin{tabular}{|c|c|c|c|c|}
\hline \multirow{3}{*}{ Market } & Public procurement & [27] & {$[52,53]$} & $\begin{array}{l}\text { As a strategic tool to influence markets, promoting } \\
\text { fair competition among suppliers of NBS and } \\
\text { incentivising innovation and investment }\end{array}$ \\
\hline & $\begin{array}{l}\text { Encouraging new } \\
\text { suppliers }\end{array}$ & [27] & {$[54,55]$} & $\begin{array}{l}\text { The government can incentivise new suppliers to } \\
\text { enter the NBS market }\end{array}$ \\
\hline & Innovation by agency & [27] & {$[56]$} & $\begin{array}{l}\text { A third party, such as a national buying agency, can } \\
\text { promote NBS innovation }\end{array}$ \\
\hline \multicolumn{5}{|c|}{$\begin{array}{l}\text { CLUSTER 3: COMMUNITY MSS } \\
\text { Initiating actor: COMMUNITY* }\end{array}$} \\
\hline \multirow{5}{*}{ Market } & IT applications & [27] & [57] & $\begin{array}{l}\text { The NGO can use IT-based applications to reduce the } \\
\text { costs and risks of trying new suppliers and products }\end{array}$ \\
\hline & Vendor cooperatives & {$[27]$} & [58] & $\begin{array}{l}\text { Act as an independent intermediary between the } \\
\text { buyer and the supplier in NBS implementation }\end{array}$ \\
\hline & $\begin{array}{l}\text { Industry } \\
\text { standardisation }\end{array}$ & [27] & {$[52]$} & $\begin{array}{l}\text { Participation in industry standardisation processes } \\
\text { can influence the industry supply to promote NBS }\end{array}$ \\
\hline & $\begin{array}{l}\text { Identification of one's } \\
\quad \text { own needs }\end{array}$ & {$[27]$} & [52] & $\begin{array}{l}\text { The identification of one's own requirements } \\
\text { regarding NBS and communication to potential } \\
\text { suppliers can influence the market }\end{array}$ \\
\hline & Joint understanding & {$[27]$} & {$[52]$} & $\begin{array}{l}\text { A joint understanding between the end-user and the } \\
\text { sellers can promote NBS products and projects }\end{array}$ \\
\hline
\end{tabular}

${ }^{*}$ For each of the clusters (in bold) the initiating actor correspond to one of the vertices of the 3-axis scheme.

\subsubsection{Step 2: Typology of Integrated Implementation Models}

The governance, financing, and business models were conceptually integrated into different types of implementation models (IM). This integration builds on the work of Lupova-Henry and Dotty on the governance of sustainable innovation [43]. LupovaHenry and Dotty define approaches based on the role of initiating actors, similarly to the 
definition in Section 2.1.1. Each IM was characterised, describing its 3 types of models, their advantages and disadvantages, and recommendations for their implementation.

\subsection{Operational Integration of Implementation Models}

\subsubsection{Step 3: Consideration of Implementation Factors}

The first step to make the conceptual integration operational to support the implementation of NBS urban projects is to introduce the context into the decision-making process. This is necessary because urban NBS projects are highly context-specific, being closely linked to a particular socio-ecological system [59]. As part of this study, 2 types of implementation factors were differentiated (for detailed information, see Table A2 in Appendix A)

(i) Context conditions, i.e., regulatory socio-cultural and economic context factors, which the project developer cannot influence as they are imposed by the specific situation of the city;

(ii) Project developer requirements, i.e., factors dependent on the end-user, such as budget or the desired participation level or scale.

An identification was made of those factors which influence the selection of governance models (GMs), financing models (FMs), or business models (BMs), as well as the implementation factors which are structurally related to the NBS project.

\subsubsection{Step 4: WHAT-WHO-HOW Implementation Scheme}

To structure the links between specific NBS projects, their implementation context, and the most suitable IM, the WHAT-WHO-HOW scheme was selected for its simplicity and operativity (Figure 3). It has previously been used to analyse governance strategies in the field of sustainable innovation [43]. This framework makes it possible to link 3 key dimensions in the implementation of NBS projects:

(i) The specific NBS project (WHAT), which is the combination of the NBS types defined and the implementation factors that are structurally related to the NBS (ownership and scale);

(ii) The initiating actors (WHO) that form the basis of the "financing and governance triangle" and will determine the nature and rules of the IM;

(iii) The implementation model (HOW) defined by the contextual factors and user requirements that also influence the governance, financing, and business models.

what

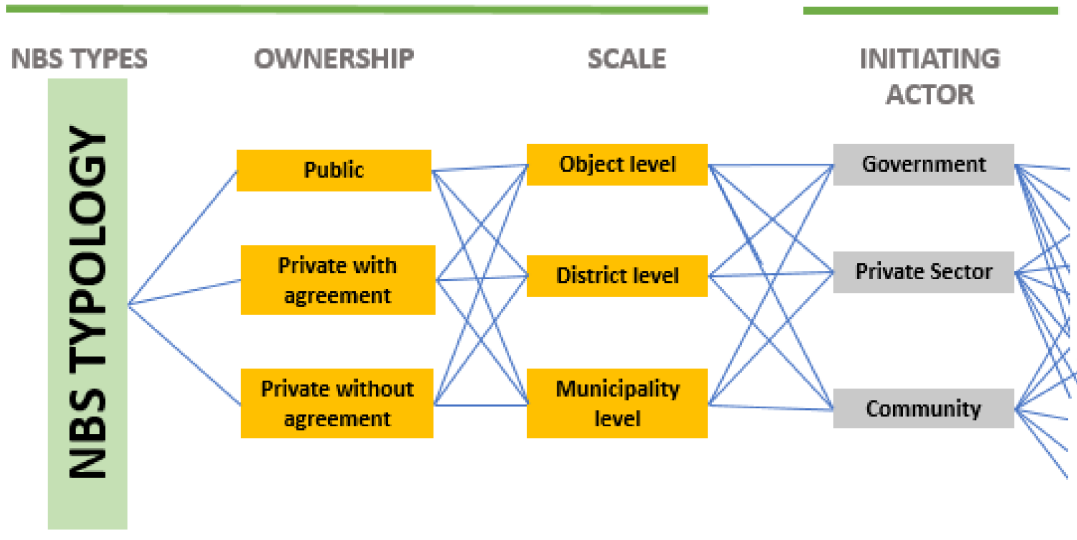

who
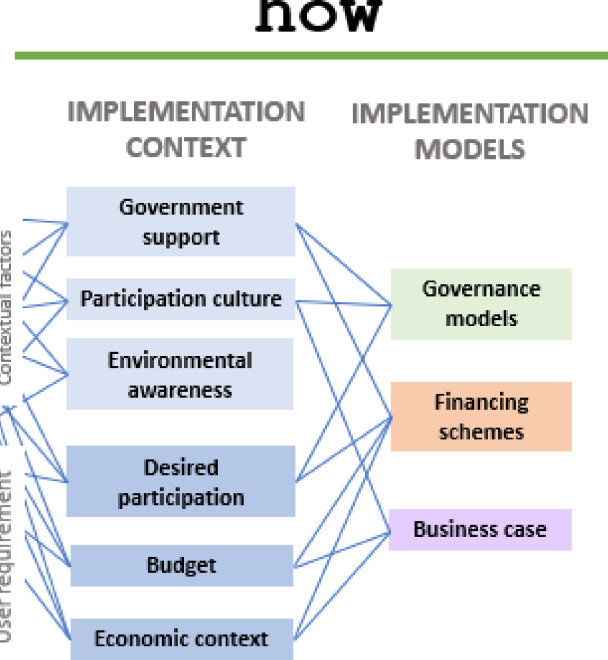

Figure 3. WHAT-WHO-HOW scheme for operative integration of IM.

To fully characterize WHAT, the list of possible NBS types was defined using the NBS typology developed in the N4C project [60]. To be able to define WHO in detail, sub-groups 
inside the 3 types of initiating actors were identified (for detailed information see Table A3 in Appendix A). The list includes object and city-scale actors, which are typically identified in the literature as the key actors in NBS implementation [7].

\subsubsection{Step 5: Suitability Matrix}

The suitability matrix includes all the possible combinations of factors for every governance and financing model. First, a prototype of the suitability matrix was built using the information collected in the previous steps. The suitability of the different models was defined based on the experience of real NBS projects, for which implementation models were analysed in the $\mathrm{N} 4 \mathrm{C}$ project (62 projects from Europe, 4 from America, and 1 from Asia) [30].

The N4C project provides an IM database of 56 of these projects and 11 projects from 4 case study cities: Milan (IT), Alcalá de Henares (SP), Szeged (HU), and Çancaya (TUR). Having discarded projects that had insufficient information on the factors that defined the governance and financing models (NBS typology, scale, ownership, initiating actor, desired participation, government support for governance, and budget for financing) or which were not real NBS implementation projects, 50 projects were then selected to link the governance models and 34 to build links regarding financing models (see Table A1 in Appendix A).

To test and adapt the first prototype, all the factors (WHAT-WHO-HOW) identified in the literature review for each governance and financing model were compared against the reviewed NBS projects. In the event of non-coincidence (see Tables A3 and A5 in Appendix A), the projects were re-evaluated to analyse the reasons and then adapt the suitability matrix to include the valid non-considered combinations.

This case study analysis showcased that most projects are multi-NBS projects (i.e., that include more than one NBS type) and only 3 projects involved single NBS typologies. Therefore, multi-NBS projects were incorporated in the matrix and an analysis of the factors that differentiate single-NBS projects from multi-NBS projects was conducted. The incorporation of multi-NBS projects was carried out using the same process: defining the WHAT-WHO-HOW factors for the projects and linking them to the IM.

\subsubsection{Step 6: Building the Business Case}

As mentioned in Section 2.1.1, the creation of a business model requires a case-by-case approach. However, the initiating actor can be supported with a narrow list of suitable and compatible options for the different elements of the business model to facilitate the creation of a specific one for their NBS project.

The SBM patterns classified by Lüdeke-Freund et al. [31] were used to facilitate the definition of business models adequate for NBS. Concurrently, the model developed by Osterwalder and Pigneur [61] was used as a basis for the definition of the business model canvas (BMC). Some of the 9 initial elements of their BSM were adjusted to tailor them more closely to the characteristics of NBS projects. This adjustment was made using as a supporting reference the work of the H2020 project Connecting Nature [32]. The 9 elements of the BMC make it possible to break down the implementation proposal into different governance, financing, and business case elements and link them to SBM patterns.

Selected governance and financing models provide a direct answer to some of the elements (key partners and key resources/investors) of the BMC, but the rest had to be defined on a case-by-case basis. To support this definition, the potential applications of SBM patterns to NBS were assessed according to 4 criteria:

(i) Scale: the SBM is applicable at the building, district, or municipal scale;

(ii) Domain: the SBM may be applicable in building environments or urban strategies;

(iii) Geographical framework: the SBM may be applicable in Europe;

(iv) Value chain: the SBM may be applicable in the business sector related to NBS. 
Each pattern was assessed according to these criteria using 3 levels (high, medium, and low) and their suitability was evaluated according to a final score. For details regarding the intermediate results of this assessment, see Table A6 in Appendix A.

\subsubsection{Step 7: IM Preselection Tool}

The suitability matrix was implemented in a web-based tool (the IM preselection tool) that is offered in an automatized form-suitable IM for specific NBS projects and implementation conditions. To ensure that the tool was accessible and user-friendly, its usability was tested in a pilot version by members of the Nature4Cities consortium and sister $\mathrm{H} 2020$ projects consortium, and attendees participating in the N4C webinars. Their feedback was collected and used to define the current version of the IM preselection tool, which can be explored in [62].

\section{Results}

3.1. Mapping of Governance, Financing, and Business Models (Market-Shaping Strategies) and Their Conceptual Integration in Implementation Models

The mapping and cluster of the 13 governance and 18 financing models identified are presented through the "governance and financing triangle" in Figure 4. On top of them, 15 market-shaping strategies that would help to define the business models are presented in Figure 5. The overlapping of both types of results, supported by the work of Lupova-Henry and Dotty [43], facilitated the definition of 4 IM approaches: State-Centric, Corporate-Centric, Society-Focused, and Collaborative. They are mapped in Figure 6 and their governance, financing, and market-shaping defining characteristics are described in Table 2.

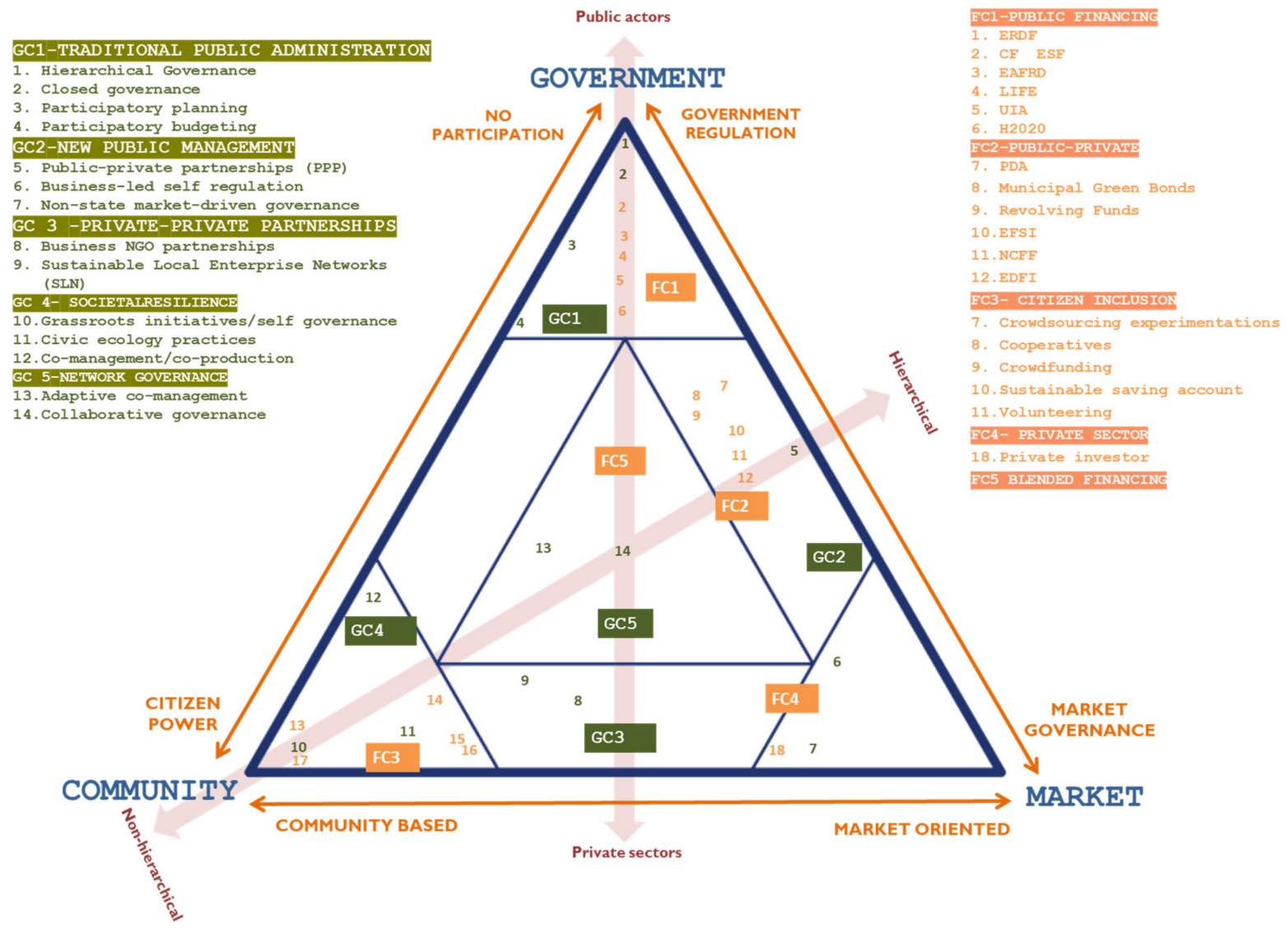

Figure 4. Map of governance and financing models. 
MSSC 2

PUBLIC MARKET

SHAPING STRATEGIES

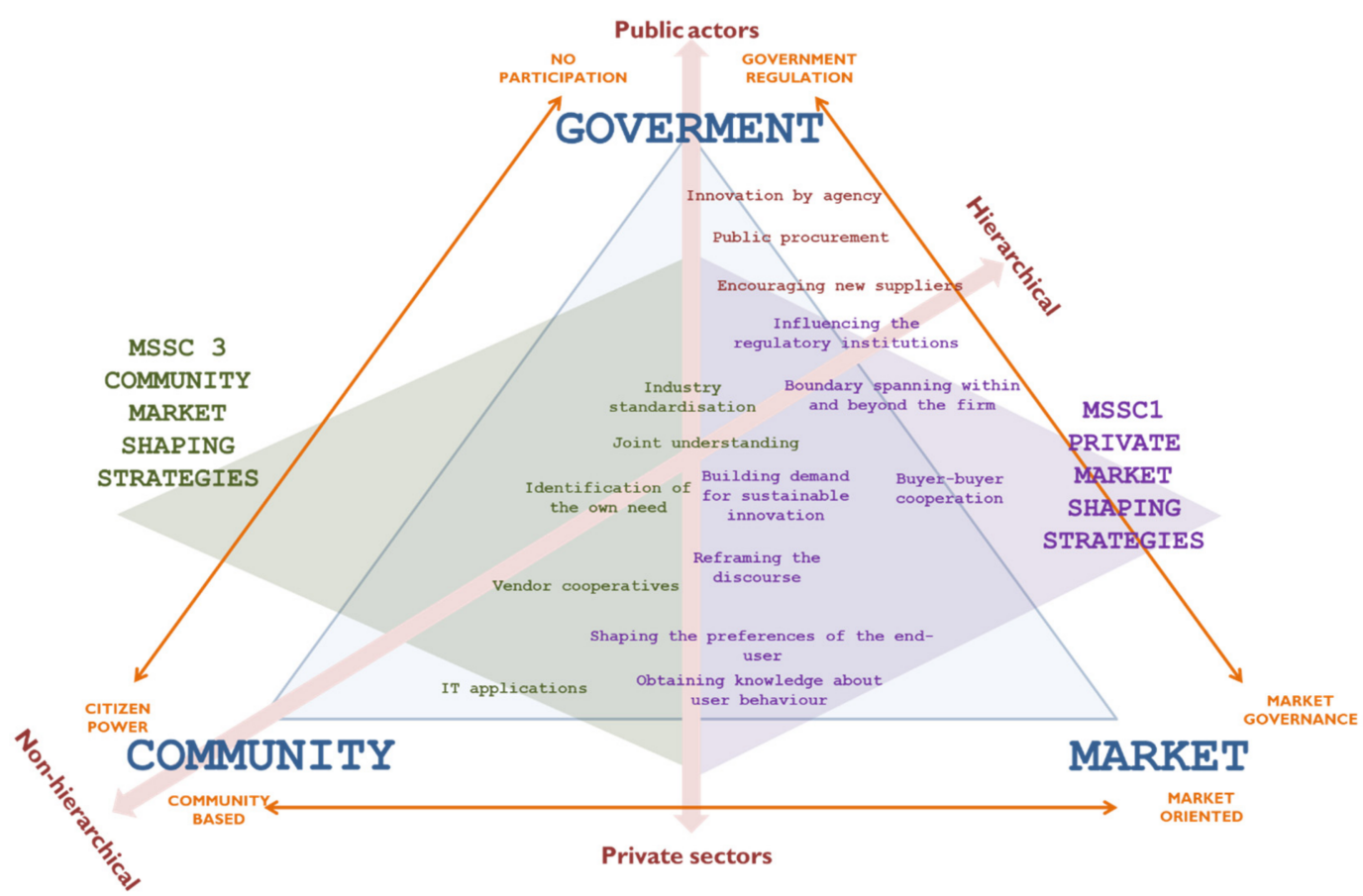

Figure 5. Map of market-shaping strategies clusters (MSSCs).

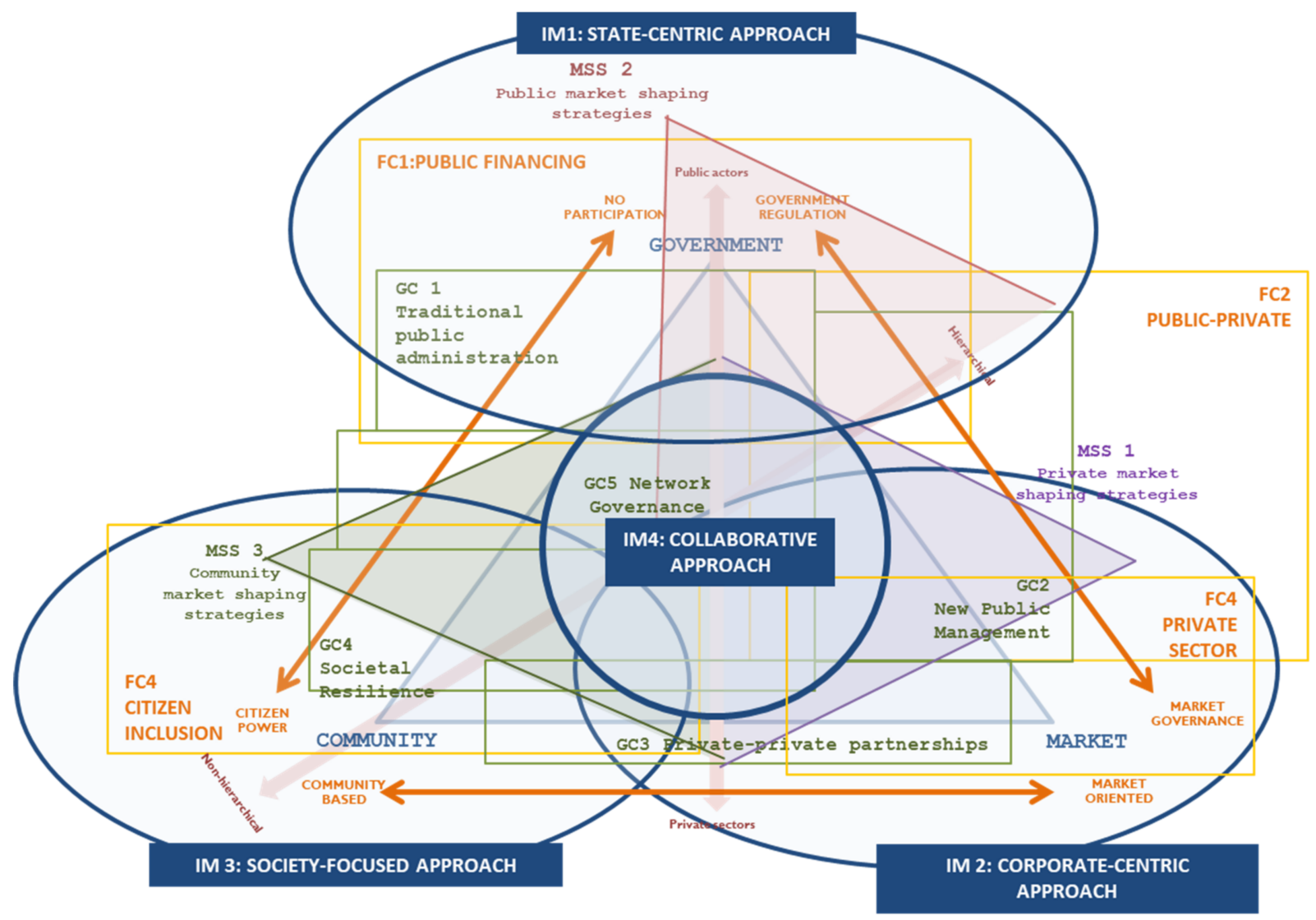

Figure 6. Map of integrated IM typology. 
Table 2. Implementation models, their advantages, disadvantages, and recommendations.

\begin{tabular}{|c|c|c|c|c|}
\hline IM & ADVANTAGES & DISADVANTAGES & RECOMMENDATIONS & SOURCES \\
\hline \multicolumn{5}{|c|}{ IM1: STATE-CENTRIC APPROACH } \\
\hline $\begin{array}{l}\text { GM } \\
\text { Traditional public } \\
\text { administration }\end{array}$ & $\begin{array}{l}\text { Could be highly } \\
\text { operational for urgent } \\
\text { problems and may } \\
\text { initially provide large } \\
\text { step-change } \\
\text { improvements. }\end{array}$ & $\begin{array}{l}\text { Less capacity for } \\
\text { aspects required by } \\
\text { NBS projects: local } \\
\text { innovation, continuous } \\
\text { improvement, and } \\
\text { highly contextualised } \\
\text { solutions. Services } \\
\text { provided by a } \\
\text { centralised entity could } \\
\text { be more vulnerable } \\
\text { to failure. }\end{array}$ & $\begin{array}{l}\text { Facilitate collaborative } \\
\text { arrangements without losing } \\
\text { the government role: steering } \\
\text { when partnerships exhibit the } \\
\text { capacity for delivering and } \\
\text { regulating when strategic } \\
\text { planning is required. }\end{array}$ & {$[35,63-65]$} \\
\hline $\begin{array}{c}\text { FM } \\
\text { Public financing }\end{array}$ & $\begin{array}{l}\text { The allocation of a } \\
\text { sufficient budget for } \\
\text { implementing and } \\
\text { maintaining NBS } \\
\text { projects can endow } \\
\text { sustainability during } \\
\text { tight financing periods. }\end{array}$ & $\begin{array}{l}\text { City budgets for green } \\
\text { development and } \\
\text { maintenance often face } \\
\text { budget constraints. } \\
\text { Financing mechanisms } \\
\text { require co-financing. }\end{array}$ & $\begin{array}{l}\text { Try the cooperation of multiple } \\
\text { funding mechanisms, } \\
\text { public-private partnerships, } \\
\text { and blended finance. }\end{array}$ & {$[10,11,66,67]$} \\
\hline $\begin{array}{c}\text { MSS } \\
\text { Public market-shaping } \\
\text { strategy }\end{array}$ & $\begin{array}{l}\text { Local governments can } \\
\text { use incentives and the } \\
\text { removal of } \\
\text { administrative barriers } \\
\text { to create partnerships } \\
\text { with businesses where } \\
\text { citizens can participate. } \\
\text { Public procurement can } \\
\text { modify markets to } \\
\text { advance policy goals, } \\
\text { promote competitive } \\
\text { alternatives, and } \\
\text { incentivise innovation. }\end{array}$ & $\begin{array}{l}\text { Lack of incentives and } \\
\text { motivation to attract } \\
\text { private investment. In } \\
\text { early-stage } \\
\text { technologies, public } \\
\text { market-creation } \\
\text { mechanisms do not } \\
\text { always lead to the } \\
\text { development of } \\
\text { sustainable innovation. }\end{array}$ & $\begin{array}{l}\text { PPP can create new } \\
\text { opportunities for efficient } \\
\text { uptake of NBS through a } \\
\text { common understanding } \\
\text { of needs. }\end{array}$ & {$[27,42,43,68-70]$} \\
\hline
\end{tabular}

\section{IM2: CORPORATE-CENTRIC APPROACH}

\section{GM}

New public

management
Fair competition in the private sector renders some processes more efficient and provides operational knowledge. Governments play important roles and they remain non-authoritative.
Could have low
legitimacy and cceptance and display power asymmetry. Not always aligned with the community. More inclusive models might be suitable, but they require conditions that are rarely met.
Public responsibilities should not be eliminated.

Government involvement in certain services ensures the efficiency of economic markets by reducing capital risks, increasing access to information, and reducing monopoly power.

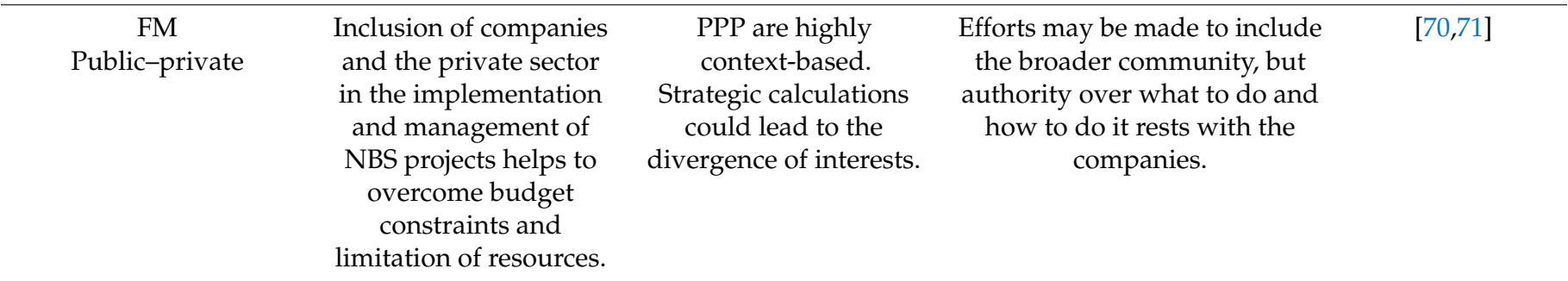


Table 2. Cont

\begin{tabular}{|c|c|c|c|c|}
\hline IM & ADVANTAGES & DISADVANTAGES & RECOMMENDATIONS & SOURCES \\
\hline $\begin{array}{c}\text { MSS } \\
\text { Private market shaping } \\
\text { strategy }\end{array}$ & $\begin{array}{l}\text { Divesting from } \\
\text { dominant solutions can } \\
\text { leverage private } \\
\text { funding, creating } \\
\text { conditions for new BM. } \\
\text { Researching the real } \\
\text { needs of end-users } \\
\text { engages the community } \\
\text { and renders solutions } \\
\text { more acceptable. } \\
\text { Strategic partnerships } \\
\text { with private actors can } \\
\text { develop in business } \\
\text { ecosystems suitable for } \\
\text { NBS projects. }\end{array}$ & $\begin{array}{l}\text { May neglect } \\
\text { environmental and } \\
\text { social values to } \\
\text { maximise economic } \\
\text { results. Utilitarian, } \\
\text { short-term use triggers } \\
\text { community rejection. } \\
\text { Influence in the } \\
\text { regulatory framework } \\
\text { could be used to } \\
\text { maximise economic } \\
\text { results and avoid } \\
\text { regulations. }\end{array}$ & $\begin{array}{l}\text { Encourage methods to transfer } \\
\text { the benefits of common goods } \\
\text { provided by NBS to the } \\
\text { initiators to stimulate private } \\
\text { investment and render NBS } \\
\text { more attractive. It is crucial to } \\
\text { include social and } \\
\text { environmental values along } \\
\text { with monetary values to } \\
\text { gain legitimacy. }\end{array}$ & {$[8,10]$} \\
\hline \multicolumn{5}{|c|}{ IM3: COMMUNITY-FOCUSED APPROACH } \\
\hline $\begin{array}{c}\text { GM } \\
\text { Societal resilience }\end{array}$ & $\begin{array}{l}\text { High legitimacy and } \\
\text { acceptance of the } \\
\text { projects as they reflect } \\
\text { local context. Can play } \\
\text { a significant role in } \\
\text { providing } \\
\text { on-the-ground } \\
\text { evidence of the } \\
\text { multiple benefits of } \\
\text { NBS. Management of } \\
\text { natural resources is one } \\
\text { field that is especially } \\
\text { well suited for these } \\
\text { types of governance. }\end{array}$ & $\begin{array}{l}\text { Bottom-up initiatives } \\
\text { often concern public } \\
\text { green spaces, relying } \\
\text { on public resources. } \\
\text { There is a limit to the } \\
\text { decentralisation of } \\
\text { public goods and } \\
\text { services. Grassroots } \\
\text { movements are } \\
\text { inherently } \\
\text { unpredictable. Active } \\
\text { society is required. }\end{array}$ & $\begin{array}{c}\text { Try to include other } \\
\text { stakeholders (especially local } \\
\text { government). The involvement } \\
\text { of scientists and NGOs helps } \\
\text { to ensure larger impacts and } \\
\text { longer-term sustainability but } \\
\text { is not mandatory. There are } \\
\text { sometimes adversarial } \\
\text { relations with government } \\
\text { and business. }\end{array}$ & {$[72,73]$} \\
\hline $\begin{array}{c}\text { FM } \\
\text { Citizen-inclusive } \\
\text { financing instruments }\end{array}$ & $\begin{array}{l}\text { Flexibility and fewer } \\
\text { requirements for } \\
\text { financing. } \\
\text { Self-financing and } \\
\text { self-management } \\
\text { projects can be } \\
\text { sustainable and } \\
\text { resilient as they are less } \\
\text { dependent on changes. }\end{array}$ & $\begin{array}{l}\text { Complexity of the civic } \\
\text { market. Glamorous } \\
\text { projects may be } \\
\text { required. Benefits may } \\
\text { not be in line with the } \\
\text { time invested. }\end{array}$ & $\begin{array}{l}\text { Try to ensure public funding to } \\
\text { complete alternative } \\
\text { financing systems. }\end{array}$ & {$[74,75]$} \\
\hline $\begin{array}{c}\text { MSS } \\
\text { Community } \\
\text { market-shaping } \\
\text { strategy }\end{array}$ & $\begin{array}{l}\text { A BM approach can } \\
\text { facilitate the } \\
\text { sustainability of } \\
\text { grassroots projects. } \\
\text { Tools such as IT-based } \\
\text { ones and vendor } \\
\text { cooperatives can define } \\
\text { industry supply and } \\
\text { monitor the market. }\end{array}$ & $\begin{array}{l}\text { May require expertise } \\
\text { that is not always } \\
\text { available. Introduction } \\
\text { of economic factors in } \\
\text { voluntary-based } \\
\text { approaches could } \\
\text { create tensions. }\end{array}$ & $\begin{array}{l}\text { Try to introduce private } \\
\text { investment through a } \\
\text { long-term partnership with } \\
\text { socially conscious companies. }\end{array}$ & {$[27,52]$} \\
\hline
\end{tabular}


Table 2. Cont

\begin{tabular}{|c|c|c|c|c|}
\hline IM & ADVANTAGES & DISADVANTAGES & RECOMMENDATIONS & SOURCES \\
\hline \multicolumn{5}{|c|}{ IM4: COLLABORATIVE ECOSYSTEM } \\
\hline $\begin{array}{c}\text { GM } \\
\text { Network governance }\end{array}$ & $\begin{array}{l}\text { Approach conceived } \\
\text { for dealing with } \\
\text { uncertainty and } \\
\text { complexity. The } \\
\text { "maturation period" of } \\
\text { some NBS projects } \\
\text { could provide an } \\
\text { opportunity for } \\
\text { long-term collaborative } \\
\text { approaches. }\end{array}$ & $\begin{array}{l}\text { Transaction costs are } \\
\text { high and } \\
\text { are usually only } \\
\text { possible in democracies. } \\
\text { Differences in } \\
\text { organisational cultures } \\
\text { between business and } \\
\text { community. }\end{array}$ & $\begin{array}{l}\text { Establish trust relationships to } \\
\text { strengthen collaboration paths. }\end{array}$ & {$[34,76-79]$} \\
\hline $\begin{array}{c}\text { FM } \\
\text { Multi-source }\end{array}$ & $\begin{array}{l}\text { More mature } \\
\text { international financing } \\
\text { landscape. High } \\
\text { suitability for large and } \\
\text { complex projects. Sense } \\
\text { of belonging renders it } \\
\text { easier to mobilise } \\
\text { efforts to obtain } \\
\text { financing from } \\
\text { different sources. }\end{array}$ & $\begin{array}{l}\text { Difficulties in accessing } \\
\text { private funding if } \\
\text { agreement among } \\
\text { stakeholders is weak. }\end{array}$ & $\begin{array}{l}\text { Ensure blended financing } \\
\text { mechanisms to achieve } \\
\text { resilient, long-term economic } \\
\text { sustainability. }\end{array}$ & {$[80]$} \\
\hline $\begin{array}{c}\text { MSS } \\
\text { Multi-source }\end{array}$ & $\begin{array}{l}\text { The business case } \\
\text { approach is crucial to } \\
\text { ensure the economic } \\
\text { sustainability of } \\
\text { collaborative projects. } \\
\text { An integrated vision } \\
\text { can also help to identify } \\
\text { missing key partners } \\
\text { and elements. }\end{array}$ & $\begin{array}{l}\text { The limited inclusion of } \\
\text { a business approach } \\
\text { could generate tensions } \\
\text { between different } \\
\text { stakeholders. }\end{array}$ & $\begin{array}{l}\text { Use the business model canvas } \\
\text { as a tool to develop the } \\
\text { business case and to identify } \\
\text { missing key partners and } \\
\text { elements. }\end{array}$ & [23] \\
\hline
\end{tabular}

\subsection{IM Preselection Tool}

The IM preselection tool presents the knowledge generated in the previous steps in a simple, easy-to-use, and automatized way. It integrates the three dimensions of the IM of NBS projects: governance, financing, and business. As illustrated in Figure 7, the tool is split into four steps to guide the users (decision-makers) on suitable IM for their NBS project. Besides those four steps, the tool also includes a Home page and a Conclusion page.

\section{START THE PROCESS}

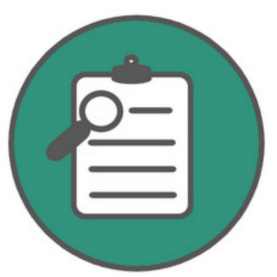

Define the NBS project
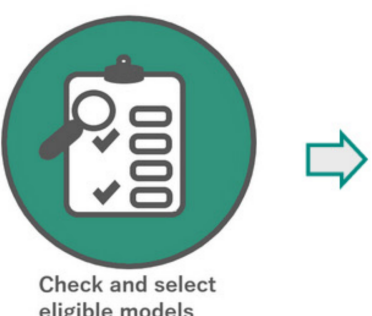

eligible models

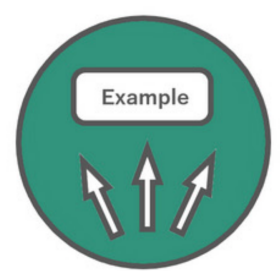

Use examples as guidance

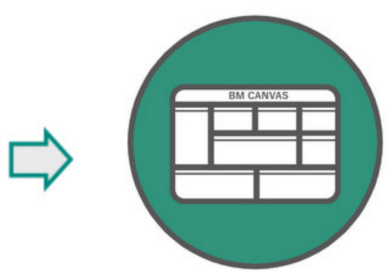

NBS Business Model Canvas

Figure 7. Process followed by the IM Preselection Tool to support the definition of IMs.

First, the users define the NBS project and implementation factors, which will restrict the number of adequate governance and financing models. Second, the users select the governance and financing models that they would like to explore. A new cluster was included in the tool to offer specific guidance regarding the financing methods related to 
financial institutions. Third, the tool provides examples of NBS projects homologous to that of the user which have applied the selected models. This provides practical examples that could be further investigated by the user and used as a guiding reference in their NBS project. In the last step, as illustrated in Figure 8, the tool presents the users with the BMC (further details about the BMC can be found in Table A7 Appendix A), where they will find the following information:

(i) The previously selected governance and financing models in the form of key partnerships and key resources/investors;

(ii) Suitable SBM patterns related to the context in which the NBS project will be develoPlease check if it's supplementary materialsped that could help in the definition of the business case;

(iii) Some questions that must be answered to complete the design of the business case appropriate to the NBS project.
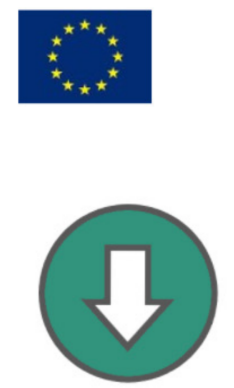

DOWNLOAD THE NBS BM CANVAS

GO BACK TO INPUTS

GO BACK TO

ELIGIBLE MODELS

FINISH THE

PROCESS
NBS BM CANVAS

NATURE

4 CITIES

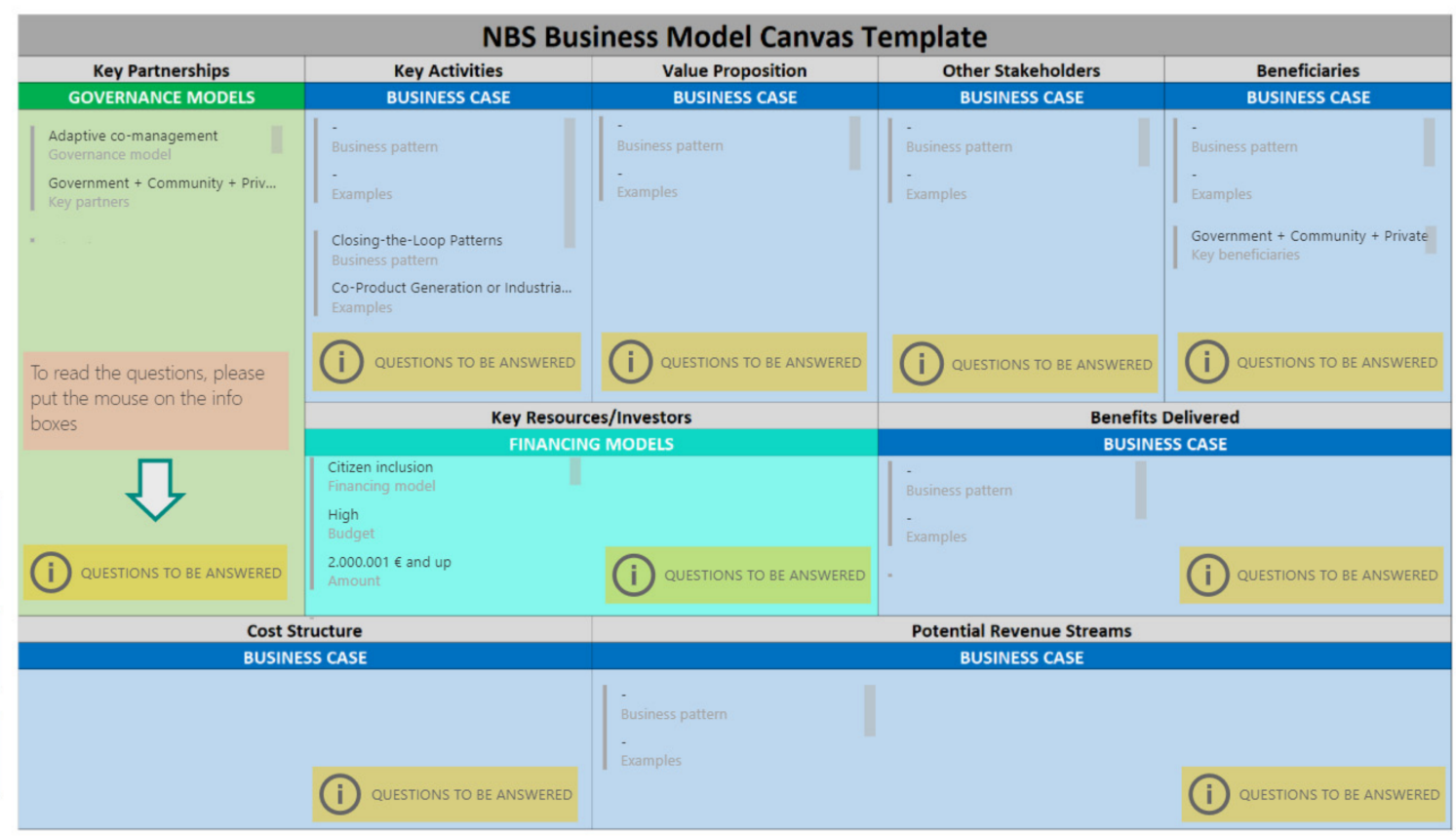

Figure 8. IM Preselection Tool BMC element visualisation.

The completed NBS BMC does not provide a one-size-fits-all solution. Instead, it provides users with information that would help define their specific IM (particularly regarding the business model) within a structure, narrowing down the potential options.

Once all steps are performed, on the Conclusion page the IM preselection tool provides a link to an NBS Implementation Handbook. Together with the results of the tool, it can be used to further guide the users (decision-makers) on the definition of the IM for their specific NBS project.

\section{Discussion and Conclusions}

This paper presents a two-fold approach (conceptual and operational) that analyses and compiles adaptable reference governance, financing, and market-shaping models to guide the development of implementation models (IMs) tailored to specific NBS projects and contextual conditions. The information gathered from the two-fold approach is embedded in a structured way into an IM preselection tool available to support decision making. 
At a conceptual level and using the current literature, governance and financing models were compiled and structured based on the roles of initiating actors. Additionally, the theoretical framework for business models was defined based on a sustainable business model (SBM) approach and market-shaping strategies. The conceptualization provides a theoretical basis to help to build tailored IMs, including the creation of specific business models. However, the conceptual level alone presents limitations regarding their application to real NBS projects. For example, as already anticipated in previous sections, business model archetypes need to be very specific to the product or solution (NBS type) for which they are generated, and therefore need to be based on practical contextual and solution-specific data. In this sense, without the empirical data collected from real NBS projects at the operational level, the framework would have missed a good characterization of suitable business models archetypes. In more general terms this means that the abstraction process required for the conceptual level does not bridge the gap between theory and practice. Thus, the definition of implementation factors and building on real NBS case studies permitted overcoming this gap.

The operational integration of the governance, financing, and business models is based on a modular approach that helps to define smaller elements of the implementation model and uses the SBM "patterns" reported in the literature as a pragmatic way to present characteristics of models. As a result, this operational integration supports adaptation to specific contexts, which, as already mentioned, cannot be achieved by only using the conceptual side. It also permits the visualization of results using the NBS business model canvas (BMC).

During this research, members of NBS-related $\mathrm{H} 2020$ projects and attendees of public workshops validated the user-friendliness of the IM preselection tool through involvement in a testing process. This process permitted solving the deficiencies detected by the first users, such as lack of clarity in the description of some concepts ("I think if you are not part of the project it's difficult to understand the terms", "Maybe more examples for communities description are needed", "Some information about what 'economic context is' would be helpful" or "I am not familiar with some terms in the business canvas therefore, I had a bit difficulty interpreting the canvas" are some of the comments that illustrate this limitation). They also highlighted the need to improve the visualisation of the BMC, suggesting making the canvas editable "so that the user can configure the different sections". Moreover, they highlighted that some examples of an already-completed canvas might help understand what kind of information is needed in each case.

However, some aspects still need further development. For example, to cover the broad range of potential NBS projects, it is necessary to include new reference case studies. As another example, the approach is focused on the urban side, as already mentioned in the Introduction, and therefore it would not be adequate for rural NBS projects. As a user experience limitation, the current version of the tool still needs to become more interactive to improve its user-friendliness. Despite the limitations, the IM preselection tool was well received by experts and attendees as a tool supporting the definition of tailored IMs for specific NBS projects.

As an important characteristic, the IM preselection tool does not offer a simple one-sizefits-all output. This means that it does not offer a final IM ready to be used, which would lead to unsuccessful implementations due to the context-specificity of urban NBS projects. As a one-size-fits-all output, it would have been also inadequate for application in the early planning/project phases where information is partial and qualitative, being too rigid and therefore ineffective. Instead, the preselection tool provides users with information that would help them define their specific IM (especially the business model) inside a structure and narrows down the potential options. For example, it considers the conditions (e.g., spatial scale) that would constrain the definition of the business model and helps to reflect on specific SBM patterns that would influence it using guiding questions. In this sense, the IM preselection tool helps to overcome information overload, which is identified in the NBS literature as one of the barriers to accessing the knowledge generated [10]. Hence, the IM 
preselection tool supports users, but is not intended to substitute their necessary reflection. As a practical use, the IM preselection tool, the IMs reported, and the NBS Implementation Handbook could easily be used in the early phases of urban NBS projects or action plans including them, e.g., the preparatory and conceptual phases, by decision-makers and/or professionals involved in NBS projects (such as urban planners or landscape architects). This method offers a set of effective and structured strategies that could be introduced in subsequent steps to the rest of the stakeholders involved, providing a starting point for an informed increasing definition of the IM that should continue during the rest of the phases of the NBS project. For example, based on contextual conditions the IM preselection tool helps to determine which different governance models are the most appropriate for different financing schemes. It also helps to define the appropriate elements in terms of business opportunities represented by the urban NBS project. Both aspects defined in a clear structured manner provide a starting point for the definition of the NBS IM that can also be further developed by users making use of the Implementation Handbook.

Author Contributions: Conceptualization, A.E.; methodology, A.E., M.A.-B. and A.S.; software, M.A.-B.; validation, A.E. and M.A.-B., formal analysis, A.E., M.A.-B., and A.S.; investigation, A.E., M.A.-B., and A.S.; data curation, A.E. and M.A.-B.; writing-original draft preparation, A.E., M.A.-B., A.S., and J.B.A.; writing—review and editing, A.E., M.A.-B., A.S., and J.B.A.; visualization, A.E. All authors have read and agreed to the published version of the manuscript.

Funding: This project has received funding from the European Union's Horizon 2020 research and innovation programme under grant agreement No 730468.

Institutional Review Board Statement: Not applicable.

Informed Consent Statement: Not applicable.

Data Availability Statement: Publicly available datasets were analyzed in this study. This data can be found here: http:/ /implementation-models.nature4cities-platform.eu/.

Acknowledgments: This study formed part of the Nature4Cities project and received funding from the European Union's Horizon 2020 research and innovation programme under Grant Agreement No 730468. The authors would like to thank Nature4Cities partners and Jorge Torres for the support received.

Conflicts of Interest: The authors declare no conflict of interest.

\section{Appendix A}

Table A1. Selected projects used in the generation process of the characterization matrix (Source [30]).

\begin{tabular}{cr}
\hline PROJECT & NBS \\
\hline Vrijburcht & Multi NBS: Private garden, Lawn, Green walls \\
\hline UK National Forest & Multi NBS: Urban forest, Protection and conservation strategies \\
\hline Park Lingezegen & $\begin{array}{c}\text { Multi NBS: Large urban public parks, Structures characterized by food and resource } \\
\text { production, Urban green space management, Urban planning strategies }\end{array}$ \\
\hline Hundertwasserhaus & Multi NBS: Choice of plants, Green roofs, Green walls and facades \\
\hline Zorrotzaurre district & $\begin{array}{c}\text { Multi NBS: Natural and semi-natural water bodies and hydrographic networks, } \\
\text { Constructed wetland and built structures for water management, Urban green space } \\
\text { management, Urban planning strategies }\end{array}$ \\
\hline Swale_Floating Food Forest & $\begin{array}{c}\text { Multi NBS: Structures characterized by food and resources production, Urban forests, } \\
\text { Urban greens space management, Urban planning strategies }\end{array}$ \\
\hline GAIA-Green Area Inner-city Agreement & $\begin{array}{r}\text { Multi NBS: Large urban public parks, Single trees, Urban green space management, } \\
\text { Urban planning strategies }\end{array}$ \\
\hline Living Green City Graz & Multi NBS: Parks and gardens, Green roofs, Green walls and facades \\
\hline
\end{tabular}


Table A1. Cont.

\begin{tabular}{|c|c|}
\hline PROJECT & NBS \\
\hline $\begin{array}{l}\text { A biotope-City and beyond-quartier } \\
\text { for Vienna }\end{array}$ & Multi NBS: Green roofs, Green walls and facades, Urban green space management \\
\hline VÄINAMERI Project & $\begin{array}{c}\text { MULTI NBS: Ecological restoration, Urban green space management, Urban planning } \\
\text { strategies }\end{array}$ \\
\hline the DakAkker & $\begin{array}{c}\text { MULTI NBS: Structures characterized by food and resources production, Green roofs, } \\
\text { Urban green spaces management }\end{array}$ \\
\hline Gomeznarro park & $\begin{array}{l}\text { MULTI NBS: Systems for erosion control, Works on soil, Natural and seminatural } \\
\text { water bodies and hydrographic networks, Constructed wetlands and built structures } \\
\text { for water management }\end{array}$ \\
\hline Green ventilation corridors in Stuttgart & MULTI NBS: Parks and gardens, Urban planning strategies \\
\hline Green Roof Strategy in Hamburg & MULTI NBS: Green roof, Urban planning strategies \\
\hline Bosco Verticale & MULTI NBS: Green roofs, Green walls and facades, Urban planning strategies \\
\hline Drain Garden in Ober-Grafendorf & $\begin{array}{l}\text { MULTI NBS: Constructed wetlands and built structures for water management, Urban } \\
\text { planning strategies, Monitoring }\end{array}$ \\
\hline $\begin{array}{l}\text { Cloudburst Management Plan in } \\
\text { Copenhagen }\end{array}$ & MULTI NBS: Constructed wetlands and built structures for water management \\
\hline $\begin{array}{l}\text { European Economic Area grants for } \\
\text { implementing Climate Adaptation } \\
\text { measures in Bratislava }\end{array}$ & $\begin{array}{c}\text { MULTI NBS: Public urban green spaces, Lawns, Singles trees, Structures associated to } \\
\text { urban networks, Green roofs, Urban planning strategies }\end{array}$ \\
\hline $\begin{array}{l}\text { Private and public funding to adapt } \\
\text { Western Harbour in Malmö }\end{array}$ & $\begin{array}{l}\text { MULTI NBS: Private gardens, Structures characterized by food and resource } \\
\text { production, Choice of plants, Constructed wetlands and built structures for water } \\
\text { management, Green roofs, Green walls and facades }\end{array}$ \\
\hline $\begin{array}{l}\text { European funds for flood protection } \\
\text { measures in Smolyan }\end{array}$ & Natural and semi-natural water bodies and hydrographic networks \\
\hline $\begin{array}{l}\text { Conservation of Baltic raised bogs in } \\
\text { Pomerania, Poland }\end{array}$ & $\begin{array}{l}\text { MULTI NBS: Natural and semi-natural water bodies and hydrographic networks, } \\
\text { Protection and conservation strategy }\end{array}$ \\
\hline $\begin{array}{l}\text { Multifunctional water management and } \\
\text { green infrastructure development in an } \\
\text { Eco district in Rouen }\end{array}$ & $\begin{array}{c}\text { MULTI NBS: Parks and gardens, Structures associated to urban networks, Urban } \\
\text { planning strategies }\end{array}$ \\
\hline $\begin{array}{l}\text { Barcelona trees tempering the } \\
\text { Mediterranean City and beyond climate }\end{array}$ & MULTI NBS: Structures associated to urban networks, Urban planning strategy \\
\hline Turbinenplatz & $\begin{array}{l}\text { MULTI NBS: Public urban green spaces, Works on soil, Constructed wetlands and } \\
\text { built structures for water management }\end{array}$ \\
\hline Connswater Community Greenway & $\begin{array}{c}\text { MULTI NBS: Large urban public parks, Structures associated to urban networks, } \\
\text { Natural and seminatural water bodies and hydrographic networks, Urban planning } \\
\text { strategies }\end{array}$ \\
\hline Green strips Amsterdam & $\begin{array}{c}\text { MULTI NBS: Structures associated with urban networks, Works on soil, Constructed } \\
\text { wetlands and built structures for water management }\end{array}$ \\
\hline Sportplaza Mercator Amsterdam & $\begin{array}{c}\text { MULTI NBS: Choice of plants, Green roofs, Green walls and facades, Urban planning } \\
\text { strategies }\end{array}$ \\
\hline Citizen Initiative Greening Canals & Natural and seminatural water bodies and hydrographic networks \\
\hline Smart City and beyond District Utrecht & $\begin{array}{l}\text { MULTI NBS: Structures associated to urban networks, Constructed wetlands and built } \\
\text { structures for water management, Green roofs, Urban planning strategies }\end{array}$ \\
\hline
\end{tabular}


Table A1. Cont.

\begin{tabular}{|c|c|}
\hline PROJECT & NBS \\
\hline Tide Park Rotterdam & $\begin{array}{l}\text { MULTI NBS: Natural and seminatural waterbodies and hydrographic networks, } \\
\text { Urban planning strategies }\end{array}$ \\
\hline Photovoltaic Roof Garden & MULTI NBS: Green roofs, Urban green space management \\
\hline The Avenue & $\begin{array}{l}\text { MULTI NBS: Choice of plants, constructed wetlands and built structures for } \\
\text { water management, Green roofs, Urban green space management }\end{array}$ \\
\hline Hanging Gardens Oberlaa & $\begin{array}{l}\text { MULTI NBS: Structures characterized by food and resource production, Green } \\
\text { walls and facades }\end{array}$ \\
\hline Kallang River-Bishan Park & $\begin{array}{c}\text { MULTI NBS: Large urban public parks, Ecological restoration, Choice of plants, } \\
\text { Natural and seminatural water bodies and hydrographic networks, Urban } \\
\text { planning strategies, Monitoring }\end{array}$ \\
\hline Thames Chase Plan & $\begin{array}{l}\text { MULTI NBS: Large urban public parks, Ecological restoration, Protection and } \\
\text { conservation strategies, Urban planning strategies }\end{array}$ \\
\hline MA 48 Green Facade & MULTI NBS: Green walls and facades, Choice of plant, Monitoring \\
\hline 7 Seasons & MULTI NBS: Private gardens, Urban planning strategies \\
\hline Urban Heat Islands Strategy Plan Vienna & $\begin{array}{c}\text { MULTI NBS: Parks and gardens, Water, Urban green space management, Urban } \\
\text { planning strategies }\end{array}$ \\
\hline Green Connections project & Urban planning strategies \\
\hline Plantation and management of an edible forest & $\begin{array}{c}\text { MULTI NBS: Parks and gardens, Ecological restoration, Choice of plants, } \\
\text { Systems for erosion control, Works on soil, Use of fauna, Protection and } \\
\text { conservation strategies, Urban planning strategies }\end{array}$ \\
\hline $\begin{array}{l}\text { Restoration of the gallery forest on the right } \\
\text { bank of the river Henares as it passes through } \\
\text { the city }\end{array}$ & $\begin{array}{l}\text { MULTI NBS: Ecological restoration, Choice of plants, Systems for erosion control, } \\
\text { Works on soil, Use of fauna, Protection and conservation strategies, Urban } \\
\text { planning strategies }\end{array}$ \\
\hline $\begin{array}{l}\text { İlhan Cavcav Park, Urban Green Space } \\
\text { Management }\end{array}$ & $\begin{array}{l}\text { MULTI NBS: Parks and gardens, ecological restoration, Choice of plants, System } \\
\text { for erosion control, Works on soil, Natural and semi-natural water bodies and } \\
\text { hydrographic network, Urban green space management, Waste management, } \\
\text { Protection and conservation strategies, Urban planning strategies, Monitoring }\end{array}$ \\
\hline İsmet İnönü Park, Water Management & $\begin{array}{c}\text { MULTI NBS: Parks and gardens, Choice of plants, Natural and semi-natural } \\
\text { water bodies and hydrographic network, Constructed wetlands and built } \\
\text { structures for water management }\end{array}$ \\
\hline Quarry Restoration: ATEg30-PERO & $\begin{array}{l}\text { MULTI NBS: Parks and gardens, Structure for food and resource production, } \\
\text { Ecological restoration, Choice of plants, Systems for erosion control, Works on } \\
\text { soil, Natural and semi-natural water bodies and hydrographic networks }\end{array}$ \\
\hline $\begin{array}{l}\text { Quarry Restoration: ATEg32-GAGGIANO, } \\
\text { TREZZANO SUL NAVIGLIO, ZIBIDO SAN } \\
\text { GIACOMO }\end{array}$ & $\begin{array}{l}\text { MULTI NBS: Parks and gardens, Structure for food and resource production, } \\
\text { Ecological restoration, Choice of plants, System for erosion control, Works on } \\
\text { soil, Natural and semi-natural water bodies and hydrographic networks, Urban } \\
\text { green spaces management, Protection and conservation strategies }\end{array}$ \\
\hline $\begin{array}{l}\text { Quarry Restoration: ATEg15-PADERNO } \\
\text { DUGAGNO }\end{array}$ & $\begin{array}{c}\text { MULTI NBS: Parks and gardens, Structure for food and resource production, } \\
\text { Ecological restoration, Choice of plants, System for erosion control, Works on } \\
\text { soil, Natural and semi-natural water bodies and hydrographic networks, Urban } \\
\text { green space management, Protection and conservation strategies }\end{array}$ \\
\hline $\begin{array}{l}\text { Quarry Restoration: ATEg20-POZZUOLO } \\
\text { MARTESANA, TRUCCAZZANO }\end{array}$ & $\begin{array}{l}\text { MULTI NBS: Parks and gardens, Structure for food and resource production, } \\
\text { Ecological restoration, Choice of plants, System for erosion control, Works on } \\
\text { soil, Natural and semi-natural water bodies and hydrographic networks, Urban } \\
\text { green space management, Protection and conservation strategies }\end{array}$ \\
\hline
\end{tabular}


Table A1. Cont.

\begin{tabular}{cr}
\hline PROJECT & NBS \\
\hline Reconstruction of Széchenyi square & $\begin{array}{c}\text { MULTI NBS: Parks and gardens, Urban network structures, Ecological } \\
\text { restoration, Choice of plants, Works on soil, Urban green spaces management, } \\
\text { Waste management, Urban planning strategies }\end{array}$ \\
\hline $\begin{array}{c}\text { Plan for the rehabilitation of the waterfront of } \\
\text { the Tisza River Part of Tisza Quay } \\
\text { in Downtown }\end{array}$ & $\begin{array}{c}\text { MULTI NBS: Parks and gardens, Urban network structures, Ecological } \\
\text { restoration, Choice of plants, Urban green spaces management, Waste } \\
\text { management, Protection and conservation strategies }\end{array}$ \\
\hline Bird-friendly school gardens & $\begin{array}{c}\text { MULTI NBS: Parks and gardens, Ecological restoration, Choice of plants, Works } \\
\text { on soil, Urban green space management, Waste management, Protection and } \\
\text { conservation strategies, Monitoring }\end{array}$ \\
\hline
\end{tabular}

Table A2. Implementation Factors (GM = governance model, FM = financing model, BM= business model).

\begin{tabular}{|c|c|c|c|c|c|c|}
\hline & IMPLEMENTATION FACTOR & & GM & FM & BM & NBS \\
\hline OWNERSHIP & $\begin{array}{l}\text { Implementation conditions for developing and } \\
\text { maintaining urban green infrastructure projects are very } \\
\text { different depending on land ownership. NBS projects are } \\
\text { frequently implemented on public land, but in a trend } \\
\text { towards urban densification, it is also necessary to include } \\
\text { private owners if a real impact is desired. }\end{array}$ & [76] & & & & $x$ \\
\hline $\begin{array}{l}\text { GOVERNMENT } \\
\text { SUPPORT }\end{array}$ & $\begin{array}{l}\text { The support of local government is decisive for } \\
\text { implementing innovative solutions such as NBS, } \\
\text { converting theories to action, facilitating collaborative } \\
\text { arrangements, steering and orienting partnerships, } \\
\text { attracting private investment through de-risking strategies } \\
\text { and incentives, shaping early-stage markets through } \\
\text { regulation, and providing public funding. }\end{array}$ & {$[66,69,81,82]$} & $x$ & $x$ & $x$ & \\
\hline $\begin{array}{l}\text { PARTICIPATION } \\
\text { CULTURE }\end{array}$ & $\begin{array}{c}\text { The success of NBS project implementation will depend on } \\
\text { community acceptance, the involvement of all categories } \\
\text { of stakeholders in the decision-making process, and the } \\
\text { extent to which the community perceives the } \\
\text { implementation process as having been transparent } \\
\text { and inclusive. }\end{array}$ & {$[59,83]$} & $x$ & & $x$ & \\
\hline $\begin{array}{l}\text { ENVIRONMENTAL } \\
\text { AWARENESS }\end{array}$ & $\begin{array}{c}\text { An awareness of the importance of ecosystems and their } \\
\text { services is required for the successful implementation of } \\
\text { NBS projects through participatory approaches. }\end{array}$ & {$[59,83]$} & & & $\mathrm{x}$ & \\
\hline SCALE & $\begin{array}{l}\text { The different types of NBS projects must be structured in } \\
\text { their relevant scales, ranging from the building scale to the } \\
\text { transboundary scale. Even when an NBS is implemented } \\
\text { at micro scales, the wider context and consequences must } \\
\text { be considered. }\end{array}$ & {$[59,76,84]$} & & & & $x$ \\
\hline $\begin{array}{c}\text { DESIRED } \\
\text { PARTICIPATION }\end{array}$ & $\begin{array}{l}\text { The initial planning of the desired involvement and } \\
\text { detailed knowledge of communities targeted for } \\
\text { implementation are very important for success. }\end{array}$ & [85] & $x$ & $\mathrm{x}$ & & \\
\hline BUDGET & $\begin{array}{l}\text { The range of available budget determines not only the } \\
\text { type of NBS but also the complexity of the governance } \\
\text { model and financing mechanism that can be used. }\end{array}$ & [7] & $x$ & $\mathrm{x}$ & $\mathrm{x}$ & \\
\hline ECONOMIC CONTEXT & $\begin{array}{l}\text { One of the most evident barriers to the implementation of } \\
\text { any urban project is the lack of financing resources for all } \\
\text { the relative costs of the project, including maintenance. }\end{array}$ & {$[7,18,85]$} & & & $\mathrm{x}$ & \\
\hline
\end{tabular}


Table A3. Initiating actors and sub-groups of them from object to city-scale.

\begin{tabular}{|c|c|c|}
\hline INITIATING ACTORS & SUB-GROUPS OF ACTORS & ROLE in NBS IMPLEMENTATION \\
\hline \multirow{3}{*}{ GOVERNMENTS } & Regional/national government & \multirow{3}{*}{$\begin{array}{l}\text { Large-scale NBS types such as parks, } \\
\text { which have a high public interest factor, } \\
\text { are often initiated by the government. } \\
\text { Due to different regulations and laws, the } \\
\text { implementation of NBS is influenced by } \\
\text { the government at all levels, both } \\
\text { positively and negatively. }\end{array}$} \\
\hline & Local government/municipality & \\
\hline & $\begin{array}{c}\text { Semi-government } \\
\text { organisations/institutions }\end{array}$ & \\
\hline \multirow[b]{4}{*}{ COMMUNITY } & NGOs/CSOs/interest groups & \multirow{4}{*}{$\begin{array}{l}\text { At the community level, the most } \\
\text { important players are citizens and NGOs. } \\
\text { Citizens: the initiation of an NBS by } \\
\text { citizens often directly affects small NBS } \\
\text { types such as neighbourhood gardens. } \\
\text { Indirectly, however, citizens exert a } \\
\text { strong influence on different NBS types } \\
\text { of all sizes. This influence occurs via } \\
\text { petitions and protests, but also through } \\
\text { inquiries to municipalities and cities as } \\
\text { well as through citizens' initiatives. } \\
\text { NGOs: as consultants and lobbyists, } \\
\text { NGOs often have a strong influence on } \\
\text { initiating NBS. NGOs can evolve from } \\
\text { citizens' initiatives. Large NGOs are often } \\
\text { politically well-connected and can thus } \\
\text { exert a strong influence on NBS via the } \\
\text { government. }\end{array}$} \\
\hline & CBOs/neighbourhood communities & \\
\hline & Citizens & \\
\hline & Research institutions & \\
\hline \multirow[b]{2}{*}{ MARKET } & Private sector & \multirow[b]{2}{*}{$\begin{array}{l}\text { The private sector and the market often } \\
\text { initiate some NBS types that are at the } \\
\text { object level. Influenced by government } \\
\text { organisations, citizens, and/or NGOs, } \\
\text { however, private and market actors can } \\
\text { also initiate other NBS types, for example } \\
\text { in the compensation for construction } \\
\text { activities or for marketing purposes. } \\
\text { Through lobbying, the private sector can } \\
\text { influence the government, NGOs, and } \\
\text { citizens. }\end{array}$} \\
\hline & Social enterprises/social entrepreneurs & \\
\hline
\end{tabular}

Table A4. Assessment of the suitability for NBS of the SBM patterns described and classified by [31].

\begin{tabular}{|c|c|c|c|c|c|c|}
\hline \multirow{2}{*}{ Pattern Group (SBM Element) } & \multicolumn{5}{|c|}{ Application Criteria } & \multirow{2}{*}{$\begin{array}{l}\text { Suitability } \\
\text { for NBS }\end{array}$} \\
\hline & 1 & 2 & 3 & 4 & Total Score & \\
\hline \multicolumn{7}{|c|}{$\begin{array}{c}\text { G1 Pricing and Revenue: Patterns that primarily address the revenue model of a business model, i.e., how offerings are priced, and } \\
\text { revenues generated [31]. }\end{array}$} \\
\hline “Differential pricing" [86] & 3 & 1 & 3 & 0 & 7 & MEDIUM \\
\hline “Freemium"[86] & 1 & 0 & 1 & 0 & 2 & LOW \\
\hline "Innovative product financing" [86] & 1 & 1 & 3 & 1 & 6 & MEDIUM \\
\hline "Subscription model" [86] & 1 & 1 & 3 & 1 & 6 & MEDIUM \\
\hline
\end{tabular}

G2 Financing: Patterns that address the financing model within a business model, i.e., how equity, debt and operating capital are acquired [31]. 
Table A4. Cont.

\begin{tabular}{|c|c|c|c|c|c|c|}
\hline \multirow{2}{*}{ Pattern Group (SBM Element) } & \multicolumn{5}{|c|}{ Application Criteria } & \multirow{2}{*}{$\begin{array}{l}\text { Suitability } \\
\text { for NBS }\end{array}$} \\
\hline & 1 & 2 & 3 & 4 & Total Score & \\
\hline "Crowdfunding" [86] & 3 & 3 & 3 & 3 & 12 & HIGH \\
\hline “Microfinance"[86] & 3 & 3 & 3 & 3 & 12 & HIGH \\
\hline "Social business model: No dividends" [87] & 1 & 1 & 3 & 3 & 8 & MEDIUM \\
\hline \multicolumn{7}{|c|}{$\begin{array}{l}\text { G3 Eco-design: Patterns that integrate ecological aspects into key activities and value propositions, i.e., how processes and offering } \\
\text { are designed to improve their ecological performance over their entire life cycle [31]. }\end{array}$} \\
\hline "Hybrid model/Gap-exploiter model" [88] & 0 & 0 & 3 & 0 & 3 & LOW \\
\hline "Maximise material productivity and energy efficiency" [0] & 3 & 3 & 3 & 1 & 10 & HIGH \\
\hline "Product design" [89] & 0 & 0 & 3 & 1 & 4 & LOW \\
\hline "Substitute with renewables and natural processes" [40] & 3 & 3 & 3 & 3 & 12 & $\mathrm{HIGH}$ \\
\hline \multicolumn{7}{|c|}{$\begin{array}{l}\text { G4 Closing-the-Loop Patterns: Patterns that help integrate the idea of circular material and energy flows into partnerships, key } \\
\text { activities, and customer channels, i.e., how materials and energy flow into, out of, and return to a company [31]. }\end{array}$} \\
\hline "Co-product generation" [90] & 1 & 3 & 3 & 3 & 10 & $\mathrm{HIGH}$ \\
\hline "Industrial symbiosis" [91] & 1 & 3 & 3 & 3 & 10 & HIGH \\
\hline "Online waste exchange platform" [91] & 0 & 0 & 3 & 1 & 4 & LOW \\
\hline “Product recycling" [88] & 1 & 0 & 3 & 1 & 5 & LOW \\
\hline "Remanufacturing/Next life sales" [88] & 0 & 0 & 3 & 1 & 4 & LOW \\
\hline “Repair" [89] & 0 & 0 & 3 & 0 & 3 & LOW \\
\hline “Reuse” [89] & 0 & 0 & 3 & 0 & 3 & LOW \\
\hline “Take back management” [92] & 0 & 0 & 3 & 0 & 3 & LOW \\
\hline "Upgrading" [88] & 0 & 0 & 3 & 0 & 3 & LOW \\
\hline
\end{tabular}

G5 Supply Chain: Patterns that modify the upstream (partners, resources, capabilities) and/or downstream (customers, relationships, channels) components of a business model, i.e., how inputs are sourced, and target groups are reached [31].

\begin{tabular}{cccccccc}
\hline "Green supply chain management" [92] & 0 & 0 & 3 & 1 & 4 & LOW \\
\hline "Inclusive sourcing"[86] & 3 & 3 & 3 & 3 & 12 & HIGH \\
\hline "Micro distribution and retail" [93] & 1 & 1 & 3 & 1 & 6 & MEDIUM \\
\hline "Physical to virtual" [86] & 3 & 3 & 3 & 3 & 12 & HIGH \\
\hline "Produce on demand" [86] & 1 & 1 & 3 & 1 & 6 & MEDIUM \\
\hline "Shorter supply chains" [94] & 1 & 1 & 3 & 1 & 6 & MEDIUM
\end{tabular}

G6 Giving Patterns: Patterns that help donate products or services to target groups in need, i.e., how costs are covered, and social target groups are reached [31].

\begin{tabular}{|c|c|c|c|c|c|c|}
\hline "Buy one, give one"[86] & 1 & 0 & 3 & 3 & 7 & MEDIUM \\
\hline "Commercially utilized social mission" [95] & 1 & 0 & 3 & 1 & 5 & MEDIUM \\
\hline \multicolumn{7}{|c|}{$\begin{array}{l}\text { G7 Access Provision Patterns: Patterns that create markets for otherwise neglected target groups, involving modified value } \\
\text { propositions, channels, revenue, pricing, and cost models, i.e., how value propositions are designed and delivered (and to } \\
\text { whom) [31]. }\end{array}$} \\
\hline "Building a marketplace" [86] & 3 & 3 & 3 & 3 & 12 & $\mathrm{HIGH}$ \\
\hline "e-Transaction platforms" [93] & 0 & 0 & 0 & 0 & 0 & LOW \\
\hline "Experience-based customer credit" [93] & 1 & 3 & 3 & 3 & 10 & HIGH \\
\hline "Last-mile grid utilities" [93] & 3 & 3 & 3 & 1 & 10 & HIGH \\
\hline "Value-for-money degrees" [93] & 0 & 0 & 1 & 0 & 1 & LOW \\
\hline
\end{tabular}


Table A4. Cont.

\begin{tabular}{|c|c|c|c|c|c|c|}
\hline \multirow{2}{*}{ Pattern Group (SBM Element) } & \multicolumn{5}{|c|}{ Application Criteria } & \multirow{2}{*}{$\begin{array}{l}\text { Suitability } \\
\text { for NBS }\end{array}$} \\
\hline & 1 & 2 & 3 & 4 & Total Score & \\
\hline “Value-for-money housing" [93] & 1 & 3 & 3 & 3 & 10 & $\mathrm{HIGH}$ \\
\hline \multicolumn{7}{|c|}{$\begin{array}{l}\text { G8 Social Mission Patterns: Patterns that integrate social target groups in need, including otherwise neglected groups, either as } \\
\text { customers or productive partners, i.e., how customers, partners, and employees are defined and integrated [31]. }\end{array}$} \\
\hline "Expertise broker" [96] & 3 & 3 & 3 & 3 & 12 & HIGH \\
\hline “Market-oriented social mission" [95] & 1 & 1 & 1 & 1 & 4 & MEDIUM \\
\hline “One-sided social mission" [95] & 1 & 3 & 3 & 3 & 10 & $\mathrm{HIGH}$ \\
\hline "Social business model: empowerment" [87] & 1 & 3 & 3 & 3 & 10 & HIGH \\
\hline “Two-sided social mission" [95] & 1 & 1 & 3 & 1 & 6 & MEDIUM \\
\hline \multicolumn{7}{|c|}{$\begin{array}{l}\text { G9 Service and Performance Patterns: Patterns that emphasize the functional and service value of products and that offer } \\
\text { performance management, i.e., how value propositions are defined and delivered [31]. }\end{array}$} \\
\hline “Pay for success" [86] & 3 & 1 & 3 & 3 & 10 & HIGH \\
\hline "Product-oriented services" [88] & 3 & 1 & 3 & 3 & 10 & $\mathrm{HIGH}$ \\
\hline “Result-oriented services" [88] & 1 & 3 & 3 & 3 & 10 & HIGH \\
\hline "Use-oriented services" [97] & 3 & 3 & 3 & 3 & 12 & HIGH \\
\hline
\end{tabular}

G10 Cooperative Patterns: Patterns that integrate a broad range of stakeholders as co-owners and co-managers, how partners are defined and how the organization is governed [31].

\begin{tabular}{|c|c|c|c|c|c|c|}
\hline "Cooperative ownership" [86] & 3 & 3 & 3 & 1 & 10 & $\mathrm{HIGH}$ \\
\hline
\end{tabular}

G11 Community Platform: Patterns that substitute resource or product ownership with community-based access to resources and products, how value propositions are defined and delivered [31].
"Sharing business" [98]
$\begin{array}{llll}1 & 3 & 3 & 3\end{array}$
10
HIGH

Table A5. Differences identified by governance model and project definition factors when comparing the combinations between the suitability matrix and the case studies.

\begin{tabular}{|c|c|c|c|c|c|c|}
\hline \multirow[b]{2}{*}{ Governance Models } & \multirow{2}{*}{$\begin{array}{l}\mathrm{N}^{\circ} \text { of Projects that } \\
\text { Introduce Changes } \\
\text { in the Models }\end{array}$} & \multicolumn{5}{|c|}{$\mathbf{N}^{\circ}$ of Projects Influencing Each Factor } \\
\hline & & $\begin{array}{l}\text { Initiating } \\
\text { Actor }\end{array}$ & Scale & Ownership & $\begin{array}{c}\text { Desired } \\
\text { Participation }\end{array}$ & $\begin{array}{l}\text { Government } \\
\text { Support }\end{array}$ \\
\hline Hierarchical & 0 & 0 & 0 & 0 & 0 & 0 \\
\hline Closed governance & 2 & 1 & 0 & 1 & 1 & 0 \\
\hline $\begin{array}{l}\text { Participatory planning } \\
\text { and budgeting }\end{array}$ & 7 & 4 & 1 & 4 & 6 & 0 \\
\hline $\begin{array}{l}\text { Public-private } \\
\text { partnership }\end{array}$ & 5 & 3 & 0 & 1 & 2 & 3 \\
\hline $\begin{array}{c}\text { Business-led } \\
\text { self-governance }\end{array}$ & 0 & 0 & 0 & 0 & 0 & 0 \\
\hline $\begin{array}{c}\text { Non-state market-driven } \\
\text { governance (NSMD) }\end{array}$ & 0 & 0 & 0 & 0 & 0 & 0 \\
\hline $\begin{array}{l}\text { Business-NGO } \\
\text { partnership }\end{array}$ & 0 & 0 & 0 & 0 & 0 & 0 \\
\hline $\begin{array}{c}\text { Sustainable local } \\
\text { enterprise network } \\
\text { (SLEN) }\end{array}$ & 1 & 0 & 0 & 1 & 0 & 0 \\
\hline
\end{tabular}


Table A5. Cont.

\begin{tabular}{|c|c|c|c|c|c|c|}
\hline \multirow[b]{2}{*}{ Governance Models } & \multirow{2}{*}{$\begin{array}{l}\mathrm{N}^{\circ} \text { of Projects that } \\
\text { Introduce Changes } \\
\text { in the Models }\end{array}$} & \multicolumn{5}{|c|}{$\mathbf{N}^{\circ}$ of Projects Influencing Each Factor } \\
\hline & & $\begin{array}{l}\text { Initiating } \\
\text { Actor }\end{array}$ & Scale & Ownership & $\begin{array}{c}\text { Desired } \\
\text { Participation }\end{array}$ & $\begin{array}{c}\text { Government } \\
\text { Support }\end{array}$ \\
\hline Co-management & 2 & 2 & 0 & 0 & 0 & 0 \\
\hline Civic ecology practices & 1 & 1 & 1 & 0 & 0 & 0 \\
\hline $\begin{array}{c}\text { Self- } \\
\text { governance/grassroots } \\
\text { initiatives }\end{array}$ & 2 & 1 & 0 & 0 & 0 & 1 \\
\hline $\begin{array}{l}\text { Collaborative } \\
\text { governance }\end{array}$ & 11 & 4 & 2 & 1 & 8 & 8 \\
\hline Adaptive governance & 4 & 4 & 0 & 0 & 3 & 4 \\
\hline $\begin{array}{c}\text { Adaptive } \\
\text { co-management }\end{array}$ & 2 & 1 & 1 & 0 & 0 & 1 \\
\hline Total & 37 & 21 & 5 & 8 & 20 & 17 \\
\hline
\end{tabular}

Table A6. Differences identified by financing model and project definition factors when comparing the combinations between the suitability matrix and the case studies.

\begin{tabular}{|c|c|c|c|c|c|c|}
\hline \multirow[b]{2}{*}{ Financing Models } & \multirow{2}{*}{$\begin{array}{l}\mathrm{N}^{\circ} \text { of Projects that } \\
\text { Introduce Changes in } \\
\text { the Models }\end{array}$} & \multicolumn{5}{|c|}{$\mathbf{N}^{\circ}$ of Projects Influencing Each Factor } \\
\hline & & $\begin{array}{l}\text { Initiating } \\
\text { Actor }\end{array}$ & Scale & Ownership & $\begin{array}{c}\text { Desired } \\
\text { Participation }\end{array}$ & $\begin{array}{c}\text { Government } \\
\text { Support }\end{array}$ \\
\hline Public & 2 & 0 & 0 & 2 & 0 & 0 \\
\hline Financing institutions & 2 & 0 & 2 & 0 & 2 & 0 \\
\hline Public-private & 9 & 0 & 1 & 3 & 8 & 9 \\
\hline Private & 8 & 4 & 0 & 0 & 6 & 2 \\
\hline Citizen inclusion & 1 & 1 & 0 & 0 & 0 & 0 \\
\hline Total & 22 & 5 & 3 & 5 & 16 & 11 \\
\hline
\end{tabular}

Table A7. Business case elements and NBS business model canvas.

\section{NBS BUSINESS MODEL CANVAS TEMPLATE}

\begin{tabular}{|c|c|c|c|c|}
\hline Key Partners & Key Activities & Value Proposition & Other Stakeholders & Beneficiaries \\
\hline $\begin{array}{l}\text { Network of key partners } \\
\text { that directly contribute to } \\
\text { deliver the value } \\
\text { proposition (strategic } \\
\text { alliances, competitors, } \\
\text { universities, etc.) }\end{array}$ & $\begin{array}{l}\text { Most important actions a } \\
\text { company must take to } \\
\text { operate successfully }\end{array}$ & $\begin{array}{l}\text { Product and services } \\
\text { creating value for specific } \\
\text { groups of beneficiaries }\end{array}$ & $\begin{array}{l}\text { External stakeholders } \\
\text { participating in the } \\
\text { relationship between the } \\
\text { NBS project and the } \\
\text { groups of beneficiaries } \\
\text { when the value } \\
\text { proposition is delivered }\end{array}$ & $\begin{array}{l}\text { Groups of people or } \\
\text { organisations an } \\
\text { enterprise aims to reach } \\
\text { and serve }\end{array}$ \\
\hline $\begin{array}{l}\text { GOVERNANCE } \\
\text { MODELS }\end{array}$ & $\begin{array}{c}\text { Eco-design patterns: } \\
\text { Product design } \\
\text { Substitute with } \\
\text { renewables and natural } \\
\text { processes } \\
\text { Closing-the-loop } \\
\text { patterns: } \\
\text { Co-product generation } \\
\text { Industrial simbiosis } \\
\text { BUSINESS CASE }\end{array}$ & $\begin{array}{c}\text { Service and } \\
\text { performance patterns: } \\
\text { Pay for success-based } \\
\text { contracting } \\
\text { Product-oriented } \\
\text { services } \\
\text { Result-oriented } \\
\text { services } \\
\text { Use-oriented services } \\
\text { BUSINESS CASE }\end{array}$ & $\begin{array}{l}\text { Community platform } \\
\text { patterns: } \\
\text { Sharing patterns } \\
\text { Cooperative patterns: } \\
\text { Cooperative ownership }\end{array}$ & $\begin{array}{l}\text { Social mission patterns: } \\
\text { One-sided social } \\
\text { mission } \\
\text { Social business model } \\
\text { Empowerment }\end{array}$ \\
\hline
\end{tabular}


Table A7. Cont.

NBS BUSINESS MODEL CANVAS TEMPLATE

\begin{tabular}{|c|c|c|c|c|}
\hline Key Partners & Key Activities & Value Proposition & Other Stakeholders & Beneficiaries \\
\hline & \multicolumn{2}{|c|}{ Key Resources/Investors } & \multicolumn{2}{|c|}{ Benefits Delivered } \\
\hline & \multicolumn{2}{|c|}{$\begin{array}{c}\text { Resources to create and offer the value proposition, } \\
\text { reach markets, maintain relationships, with } \\
\text { beneficiaries, earn revenues (physical, financing, } \\
\text { intellectual or human) }\end{array}$} & $\begin{array}{l}\text { Those economic environ } \\
\text { the value proposition is } p\end{array}$ & $\begin{array}{l}\text { nd social benefits that } \\
\text { to customer segments }\end{array}$ \\
\hline & \multirow{5}{*}{\multicolumn{2}{|c|}{ FINANCING MODELS }} & Access pro & batterns \\
\hline & & & Building & tplace \\
\hline & & & Last-mil & \\
\hline & & & Value-for-1 & housing \\
\hline & & & BUSIN & ASE \\
\hline \multicolumn{3}{|c|}{ Cost Structure } & Potential Revenue Strea & \\
\hline \multirow{4}{*}{\multicolumn{3}{|c|}{$\begin{array}{c}\text { Cost incurred to create and deliver value, to maintain } \\
\text { beneficiaries, and generate new revenues }\end{array}$}} & ny generates from each grot & eficiaries \\
\hline & & & Pricing and revenue patte & \\
\hline & & & nnovative product finan & \\
\hline & & & Subscription model & \\
\hline \multicolumn{3}{|c|}{ BUSINESS CASE } & BUSINESS CASE & \\
\hline
\end{tabular}

\section{References}

1. Nesshöver, C.; Assmuth, T.; Irvine, K.N.; Rusch, G.M.; Waylen, K.A.; Delbaere, B.; Haase, D.; Jones-Walters, L.; Keune, H.; Kovacs, E.; et al. The science, policy and practice of nature-based solutions: An interdisciplinary perspective. Sci. Total Environ. 2017, 579, 1215-1227. [CrossRef] [PubMed]

2. Zwierzchowska, I.; Fagiewicz, K.; Poniży, L.; Lupa, P.; Mizgajski, A. Introducing nature-based solutions into urban policy-facts and gaps. Case study of Poznań. Land Use Policy 2019, 85, 161-175. [CrossRef]

3. Dorst, H.; van der Jagt, A.; Raven, R.; Runhaar, H. Urban greening through nature-based solutions-Key characteristics of an emerging concept. Sustain. Cities Soc. 2019, 49, 101620. [CrossRef]

4. Kumar, P.; Debele, S.E.; Sahani, J.; Rawat, N.; Marti-Cardona, B.; Alfieri, S.M.; Basu, B.; Basu, A.S.; Bowyer, P.; Charizopoulos, N.; et al. Nature-based solutions efficiency evaluation against natural hazards: Modelling methods, advantages and limitations. Sci. Total Environ. 2021, 784, 147058. [CrossRef]

5. Gallotti, G.; Santo, M.A.; Apostolidou, I.; Alessandri, J.; Armigliato, A.; Basu, B.; Debele, S.; Domeneghetti, A.; Gonzalez-Ollauri, A.; Kumar, P.; et al. On the management of nature-based solutions in open-air laboratories: New insights and future perspectives. Resources 2021, 10, 36. [CrossRef]

6. Ruangpan, L.; Vojinovic, Z.; di Sabatino, S.; Leo, L.S.; Capobianco, V.; Oen, A.M.P.; Mcclain, M.E.; Lopez-Gunn, E. Nature-based solutions for hydro-meteorological risk reduction: A state-of-the-art review of the research area. Nat. Hazards Earth Syst. Sci. 2020, 20, 243-270. [CrossRef]

7. Ershad Sarabi, S.; Han, Q.; LRomme, A.G.; de Vries, B.; Wendling, L. Key Enablers of and Barriers to the Uptake and Implementation of Nature-Based Solutions in Urban Settings: A Review. Resources 2019, 8, 121. [CrossRef]

8. Le Feuvre, M.; Medway, D.; Warnaby, G.; Ward, K.; Goatman, A. Understanding stakeholder interactions in urban partnerships. Cities 2016, 52, 55-65. [CrossRef]

9. Augusto, B.; Roebeling, P.; Rafael, S.; Ferreira, J.; Ascenso, A.; Bodilis, C. Short and medium- to long-term impacts of nature-based solutions on urban heat, Sustain. Cities Soc. 2020, 57, 102122. [CrossRef]

10. Kabisch, N.; Bonn, A.; Stadler, J.; Korn, H. Nature-based solutions to climate change mitigation and adaptation in urban areas and their rural surroundings-Successes, challenges and evidence gaps—towards management and policy recommendations. Expert Workshop Doc. 2011, 21, 39.

11. Kremer, P.; Hamstead, Z.; Haase, D.; McPhearson, T.; Frantzeskaki, N.; Andersson, E.; Kabisch, N.; Larondelle, N.; Rall, E.L.; Voigt, A.; et al. Key insights for the future of urban ecosystem services research. Ecol. Soc. 2016, 21, 29. [CrossRef]

12. Frantzeskaki, N.; Tilie, N. The Dynamics of Urban Ecosystem Governance in Rotterdam, The Netherlands. Ambio 2014, 43, 542-555. [CrossRef]

13. Hansen, R.; Frantzeskaki, N.; McPhearson, T.; Rall, E.; Kabisch, N.; Kaczorowska, A.; Kain, J.H.; Artmann, M.; Pauleit, S. The uptake of the ecosystem services concept in planning discourses of European and American cities. Ecosyst. Serv. 2015. [CrossRef]

14. Naumann, S.; Gerardo, A.; Berry, P. Assessment of the Potential of Ecosystem-Based Approaches to Climate Change Adaptation and Mitigation in Europe; Final Report to the European Commission, DG Environment; Oxford University: Oxford, UK, 2011.

15. RIBA. RIBA Plan of Work 2020 Overview; RIBA: London, UK, 2020. 
16. Van der Jagt, A.P.N.; Raven, R.; Dorst, H.; Runhaar, H. Nature-based innovation systems. Environ. Innov. Soc. Trans. 2019, 35, 202-216. [CrossRef]

17. Albert, C.; Schröter, B.; Haase, D.; Brillinger, M.; Henze, J.; Herrmann, S.; Gottwald, S.; Guerrero, P.; Nicolas, C.; Matzdorf, B. Addressing societal challenges through nature-based solutions: How can landscape planning and governance research contribute? Landsc. Urban Plan. 2019, 182, 12-21. [CrossRef]

18. Raymond, C.M.; Frantzeskaki, N.; Kabisch, N.; Berry, P.; Breil, M.; Nita, M.R.; Geneletti, D.; Calfapietra, C. A framework for assessing and implementing the co-benefits of nature-based solutions in urban areas. Environ. Sci. Policy. 2017, 77, 15-24. [CrossRef]

19. Qiao, X.-J.; Kristoffersson, A.; Randrup, T.B. Challenges to implementing urban sustainable stormwater management from a governance perspective: A literature review. J. Clean. Prod. 2018, 196, 943-952. [CrossRef]

20. Frantzeskaki, N.; Kabisch, N. Designing a knowledge co-production operating space for urban environmental governance-Lessons from Rotterdam, Netherlands and Berlin, Germany. Environ. Sci. Policy 2015, 62, 90-98. [CrossRef]

21. Ronchi, S.; Arcidiacono, A.; Pogliani, L. Integrating green infrastructure into spatial planning regulations to improve the performance of urban ecosystems. Insights from an Italian case study. Sustain. Cities Soc. 2020, 53, 101907. [CrossRef]

22. European Commission. Towards an EU Research and Innovation Policy Agenda for Nature-Based Solutions E Re-Naturing Cities; European Commission: Luxembourg, 2015. [CrossRef]

23. Mayor, B.; Zorrilla-Miras, P.; le Coent, P.; Biffin, T.; Dartée, K.; Peña, K.; Graveline, N.; Marchal, R.; Nanu, F.; Scrieu, A.; et al. Natural Assurance Schemes Canvas: A Framework to Develop Business Models for Nature-Based Solutions Aimed at Disaster Risk Reduction. Sustainability 2021, 13, 1291. [CrossRef]

24. Mayor, B.; Toxopeus, H.; McQuaid, S.; Croci, E.; Lucchitta, B.; Reddy, S.E.; Egusquiza, A.; Altamirano, M.A.; Trumbic, T.; Tuerk, A.; et al. State of the art and latest advances in exploring business models for nature-based solutions. Sustainability 2021, 13, 7413. [CrossRef]

25. Ernstson, H. The social production of ecosystem services: A framework for studying environmental justice and ecological complexity in urbanized landscapes. Landsc. Urban Plan. 2013, 109, 7-17. [CrossRef]

26. Almenar, J.B.; Elliot, T.; Rugani, B.; Philippe, B.; Gutierrez, T.N.; Sonnemann, G.; Geneletti, D. Nexus between nature-based solutions, ecosystem services and urban challenges. Land Use Policy 2021, 100, 104898. [CrossRef]

27. Knight, L.; Pfeiffer, A.; Scott, J. Supply market uncertainty: Exploring consequences and responses within sustainability transitions. J. Purch. Supply Manag. 2015, 21, 167-177. [CrossRef]

28. UN Statistical Commission. A Recommendation on the Method to Delineate Cities, Urban and Rural Areas Comparisons, for International Statistical; UN Statistical Commission. 2020. Available online: https:/ / ec.europa.eu/eurostat/cros/system/files/ bg-item3j-recommendation-e.pdf (accessed on 18 October 2021).

29. Healey, P. Creativity and urban governance. Policy Stud. 2004, 25, 87-102. [CrossRef]

30. Nature Based Solutions-Implementation Models Database. n.d. Available online: http://implementation-models.nature4citiesplatform.eu/ (accessed on 18 October 2021).

31. Lüdeke-Freund, F.; Carroux, S.; Joyce, A.; Massa, L.; Breuer, H. The sustainable business model pattern taxonomy-45 patterns to support sustainability-oriented business model innovation. Sustain. Prod. Consum. 2018, 15, 145-162. [CrossRef]

32. McQuaid, S. Nature-Based Solutions Business Model Canvas Guidebook. 2019. Available online: https://connectingnature.eu/ sites / default/files/downloads/NBC-BMC-Booklet-Final-\%28for-circulation\%29.pdf (accessed on 26 October 2021).

33. Moretto, L. Application of the "Urban Governance Index" to water service provisions: Between rhetoric and reality. Habitat Int. 2015, 49, 435-444. [CrossRef]

34. Chaffin, B.C.; Gosnell, H.; Cosens, B.a. A decade of adaptive governance scholarship: Synthesis and future directions. Ecol. Soc. 2014, 19, 56. [CrossRef]

35. Lemos, M.C.; Agrawal, A. Environmental Governance. Annu. Rev. Environ. Resour. 2006, 31, 297-325. [CrossRef]

36. Egusquiza, A.; Sopelana, A.; Lotteau, M.; Larrey-Lassale, P.; Massa, E.; Pinto, G.; Montané, S.; Rozanska, E.M.; Zukowska, S.; Hernández, B.J.; et al. D1.2-NBS Implementation Models Typology. 2017. Available online: https: / /9e99b973-33ae-43f5-b05afbba8e8b1314.filesusr.com/ugd/55d29d_bf62bb2029dc4b68a339ab2c10107dad.pdf (accessed on 26 October 2021).

37. Abbott, K.W.; Snidal, D. Chapter two. The Governance Triangle: Regulatory Standards Institutions and the Shadow of the State; The Politics of Global Regulation; Princeton University Press: Princeton, NJ, USA, 2009; pp. 44-88. [CrossRef]

38. Arnstein, S.R. A Ladder of Citizen Participation. J. Am. Inst. Plan. 1969, 35, 216-224. [CrossRef]

39. Kochskämper, E.; Challies, E.; Newig, J.; Jager, N.W. Participation for effective environmental governance? Evidence from Water Framework Directive implementation in Germany, Spain and the United Kingdom. J. Environ. Manag. 2016, 181, 737-748. [CrossRef] [PubMed]

40. Geissdoerfer, M.; Vladimirova, D.; Evans, S. Sustainable business model innovation: A review. J. Clean. Prod. 2018, 198, 401-416. [CrossRef]

41. Bocken, N.M.P.; Short, S.W.; Rana, P.; Evans, S. A literature and practice review to develop sustainable business model archetypes. J. Clean. Prod. 2014, 65, 42-56. [CrossRef]

42. Foxon, T.; Pearson, P. Overcoming barriers to innovation and diffusion of cleaner technologies: Some features of a sustainable innovation policy regime. J. Clean. Prod. 2008, 16 (Suppl. 1), S148-S161. [CrossRef] 
43. Lupova-Henry, E.; Dotti, N.F. Governance of sustainable innovation: Moving beyond the hierarchy-market-network trichotomy? A systematic literature review using the 'who-how-what' framework. J. Clean. Prod. 2019, 210, 738-748. [CrossRef]

44. Planko, J.; Cramer, J.; Hekkert, M.P.; Chappin, M.M.H. Combining the technological innovation systems framework with the entrepreneurs' perspective on innovation. Technol. Anal. Strateg. Manag. 2017, 29, 614-625. [CrossRef]

45. Dewberry, E.; Sherwin, C. Visioning Sustainability through Design. Greener Manag. Int. 2002, 2002, 125-138. [CrossRef]

46. Van Osch, W.; Avital, M. The road to Sustainable Value: The path-dependent construction of sustainable innovation as sociomaterial practices in the car industry. In Positive Design and Appreciative Construction: From Sustainable Development to Sustainable Value; Michel, A., Thatchenkery, T., Cooperrider, D.L., Avital, M., Eds.; Emerald Group Publishing Limited: Bingley, UK, 2010; pp. 99-116. [CrossRef]

47. Kennedy, S.; Whiteman, G.; van den Ende, J. Radical Innovation for Sustainability: The Power of Strategy and Open Innovation. Long Range Plann. 2017, 50, 712-725. [CrossRef]

48. Wagner, M. Sustainability-related innovation and competitivenessenhancing regulation: A qualitative and quantitative analysis in the context of open innovation. Int. J. Innov. Sustain. Dev. 2011, 5, 371-388. [CrossRef]

49. Arnold, M. Fostering sustainability by linking co-creation and relationship management concepts. J. Clean. Prod. 2017, 140, 179-188. [CrossRef]

50. Przychodzen, W.; Przychodzen, J.; Lerner, D.A. Critical factors for transforming creativity into sustainability. J. Clean. Prod. 2016, 135, 1514-1523. [CrossRef]

51. Di Gasbarro, F.; Rizzi, F.; Frey, M. Sustainable institutional entrepreneurship in practice: Insights from SMEs in the clean energy sector in Tuscany (Italy). Int. J. Entrep. Behav. Res. 2018, 24, 476-498. [CrossRef]

52. Ulkuniemi, P.; Araujo, L.; Tähtinen, J. Purchasing as market-shaping: The case of component-based software engineering. Ind. Mark. Manag. 2015, 44, 54-62. [CrossRef]

53. Uyarra, E.; Flanagan, K. Understanding the Innovation Impacts of Public Procurement. Eur. Plan. Stud. 2010, 18, 123-143. [CrossRef]

54. Caldwell, N.; Walker, H.; Harland, C.; Knight, L.; Zheng, J.; Wakeley, T. Promoting competitive markets: The role of public procurement. J. Purch. Supply Manag. 2005, 11, 242-251. [CrossRef]

55. Walker, H.; Knight, L.; Harland, C. Outsourced Services and 'Imbalanced' Supply Markets. Eur. Manag. J. 2006, 24, 95-105. [CrossRef]

56. Phillips, W.; Knight, L.; Caldwell, N.; Warrington, J. Policy through procurement-The introduction of digital signal process (DSP) hearing aids into the English NHS. Health Policy 2007, 80, 77-85. [CrossRef]

57. Banker, R.D.; Mitra, S. Procurement models in the agricultural supply chain: A case study of online coffee auctions in India, Electron. Commer. Res. Appl. 2007, 6, 309-321. [CrossRef]

58. Santos, F.M. A Positive Theory of Social Entrepreneurship. J. Bus. Ethics. 2012, 111, 335-351. [CrossRef]

59. Cohen-Shacham, E.; Andrade, A.; Dalton, J.; Dudley, N.; Jones, M.; Kumar, C.; Maginnis, S.; Maynard, S.; Nelson, C.R.; Renaud, F.G.; et al. Core principles for successfully implementing and upscaling Nature-based Solutions. Environ. Sci. Policy. 2019, 98, 20-29. [CrossRef]

60. N4C Project. NBS Multi-Scalar and Multi-Thematic Typology and Associated Database. 2018. Available online: https://9e99b973 -33ae-43f5-b05a-fbba8e8b1314.filesusr.com/ugd/55d29d_8813db2df690497e80740537b6a8a844.pdf (accessed on 18 October 2021).

61. Osterwalder, A.; Pigneur, Y. Business Model Generation; John Wiley \& Sons Limited: Chiechester, UK, 2010.

62. TECNALIA, IM Preselction Tool. 2020. Available online: https://app.powerbi.com/view?r=eyJrIjoiNjY1M2YyODctNjcxNi0 0OGI4LWE4YjctMWViOTZkNWI2ZGY5IiwidCI6ImIyMzViNjdjLWJmNDgtNDY3MS1iMWExLWRhNDQ0YzFiZWY2

NiIsImMiOjh9 (accessed on 18 February 2021).

63. Arnouts, R.; van der Zouwen, M.; Arts, B. Analysing governance modes and shifts-Governance arrangements in Dutch nature policy. For. Policy Econ. 2012, 16, 43-50. [CrossRef]

64. Kooiman, J. Chapter 1 Setting the Stage. In Governing as Governance; SAGE Publications Ltd.: London, UK, 2003 ; pp. 3-25. [CrossRef]

65. Ahern, J. From fail-safe to safe-to-fail: Sustainability and resilience in the new urban world. Landsc. Urban Plan. 2011, 100, 341-343. [CrossRef]

66. Davies, C.; Hansen, R.; Rall, E.; Pauleit, S.; Lafortezza, R.; de Bellis, Y.; Santos, A.; Tosics, I. Green Infrastructure Planning and Implementation. 2015, p. 134. Available online: https://www.academia.edu/18650115/Green_Infrastructure_Planning_and_ Implementation (accessed on 26 October 2021). [CrossRef]

67. Baur, J.W.R.; Tynon, J.F.; Gómez, E. Attitudes about urban nature parks: A case study of users and nonusers in Portland, Oregon. Landsc. Urban Plan. 2013, 117, 100-111. [CrossRef]

68. Sáez-Martínez, F.J.; González-Moreno, Á.; Hogan, T. The role of university in eco-entrepreneurship: Evidence from the eurobarometer survey on attitudes of european entrepreneurs towards eco-innovation. Environ. Eng. Manag. J. 2014, 13, $2541-2549$. [CrossRef]

69. Frantzeskaki, N.; Wittmayer, J.; Loorbach, D. The role of partnerships in "realising" urban sustainability in Rotterdam's City Ports Area, the Netherlands. J. Clean. Prod. 2014, 65, 406-417. [CrossRef]

70. UNDP. Joint Venture Public-Private Partnerships for Urban Environmental Services: Report on UNDP/PPPUE's Project Development Facility (1995-1999). PPP working paper series vol II; UNDP: New York, NY, USA, 2000. 
71. Bernstein, S.; Cashore, B. Can non-state global governance be legitimate? An analytical framework. Regul. Gov. 2007, 1, 347-371. [CrossRef]

72. Anguelovski, I. Beyond a Livable and Green Neighborhood: Asserting Control, Sovereignty and Transgression in the Casc Antic of Barcelona. Int. J. Urban Reg. Res. 2013, 37, 1012-1034. [CrossRef]

73. Bendt, P.; Barthel, S.; Colding, J. Civic greening and environmental learning in public-access community gardens in Berlin. Landsc. Urban Plan. 2013, 109, 18-30. [CrossRef]

74. De Crescenzo, V.; Botella-Carrubi, D.; García, M.R. Civic crowdfunding: A new opportunity for local governments. J. Bus. Res. 2021, 123, 580-587. [CrossRef]

75. Gooch, D.; Kelly, R.M.; Stiver, A.; van der Linden, J.; Petre, M.; Richards, M.; Klis-Davies, A.; MacKinnon, J.; Macpherson, R.; Walton, $\mathrm{C}$. The benefits and challenges of using crowdfunding to facilitate community-led projects in the context of digital civics. Int. J. Hum. Comput. Stud. 2020, 134, 33-43. [CrossRef]

76. Lindholm, G. The implementation of green infrastructure: Relating a general concept to context and site. Sustainability 2017, 9, 610. [CrossRef]

77. Dietz, T.; Ostrom, E.; Stern, P.C. The struggle to govern the commons, Urban Ecol. An Int. Perspect. Interact. Between Humans Nat. 2008, 1907, 611-622. [CrossRef]

78. Schultz, L.; Folke, C.; Österblom, H.; Olsson, P. Adaptive governance, ecosystem management, and natural capital: Figure 1. Proc. Natl. Acad. Sci. USA 2015, 112, 7369-7374. [CrossRef] [PubMed]

79. Folke, C.; Hahn, T.; Olsson, P.; Norberg, J. Adaptive Governance of Social-Ecological System. Annu. Rev. Environ. Resour. 2005, 30, 441-473. [CrossRef]

80. Echeverri, L.G. Investing for rapid decarbonization in cities. Curr. Opin. Environ. Sustain. 2018, 30, 42-51. [CrossRef]

81. Hamann, R.; April, K. On the role and capabilities of collaborative intermediary organisations in urban sustainability transitions. J. Clean. Prod. 2013, 50, 12-21. [CrossRef]

82. Woolthuis, R.K.; Hooimeijer, F.; Bossink, B.; Mulder, G.; Brouwer, J. Institutional entrepreneurship in sustainable urban development: Dutch successes as inspiration for transformation. J. Clean. Prod. 2013, 50, 91-100. [CrossRef]

83. Jeunken, Y.; Breukers, S.; Karababa, E. D5.2 Citizen and Stakeholder Engagement Strategies and Tools for NBS Implementation 2018. Available online: https:/ /9e99b973-33ae-43f5-b05a-fbba8e8b1314.filesusr.com/ugd/55d29d_f6caf30a71494d22aed6f867 281a3529.pdf (accessed on 18 October 2021).

84. Barbano, G. Egusquiza, A. Interconnection between scales for friendly and affordable sustainable urban districts retrofitting. 6th Int. Build. Phys. Conf. IBPC 2015, 78, 1853-1858. [CrossRef]

85. Baptiste, A.K.; Foley, C.; Smardon, R. Understanding urban neighborhood differences in willingness to implement green infrastructure measures: A case study of Syracuse, NY. Landsc. Urban Plan. 2015, 136, 1-12. [CrossRef]

86. Clinton, L.; Whisnant, R. Model Behavior: 20 Business Model Innovations for Sustainability; Sustainability: New York, NY, USA, 2014. Available online: https://sun-connect-news.org/fileadmin/DATEIEN/Dateien/New/model_behavior_20_business_model_ innovations_for_sustainability.pdf (accessed on 20 May 2018).

87. Michelini, L.; Fiorentino, D. New business models for creating shared value. Soc. Responsib. J. 2012, 8, 561-577. [CrossRef]

88. Planing, P. Business Model Innovation in a Circular Economy Reasons for Non-Acceptance of Circular Business Models. Open J. Bus. Model Innov. 2014, 1, 11.

89. Kiørboe, N. Moving Towards a Circular Economy: Succesfull Nordic Business Models: Policy Brief; Nordic Council of Ministers: Copenhagen, Denmark, 2015.

90. Albino, V.; Fraccascia, L. The industrial symbiosis approach: A classification of business models. Procedia Environ. Sci. Eng. Manag. 2015, 2, 217-223.

91. Beltramello, A.; Haie-Fayle, L.; Pilat, D. Why New Business Models Matter for Green Growth; OECD Green Papers No 2013/01; OECD Publishing: Paris, France, 2013.

92. Bisgaard, T.; Henriksen, K.; Bjerre, M. Green Business Model Innovation: Conceptualisation, Next Practice and Policy; Nordic Innovation: Oslo, Norway, 2012.

93. Jenkins, B.; Ishikawa, E.; Geaneotes, A.; Baptista, P.; Masuoka, T. Accelerating Inclusive Business Opportunities: Business Models that Make a Difference; DC IFC: Washington, WA, USA, 2011; pp. 1-50.

94. The Crowd \& Fishburn. The Wisdom of the Crowd: New Business Models. Leading Experts Share Their Views on the Emerging Generation of More Sustainable Business Models; The Crowd \& Fishburn: London, UK, 2014.

95. Dohrmann, S.; Raith, M.; Siebold, N. Monetizing social value creation-A business model approach. Entrep. Res. J. 2015, 5, 127-154. [CrossRef]

96. Zeyen, A.; Beckmann, M.; Akhavan, R. Social Entrepreneurship Business Models: Managing Innovation for Social and Economic Value Creation. In Managementperspektiven für die Zivilgesellschaft des 21. Jahrhunderts; Manag. Als Lib. Art; von Müller, C., Zinth, C.-P., Eds.; Springer Fachmedien Wiesbaden: Wiesbaden, Germany, 2014; pp. 107-132. [CrossRef]

97. Tukker, A. Eight types of product-service system: Eight ways to sustainability? Experiences from SusProNet. Bus. Strateg. Environ. 2004, 13, 246-260. [CrossRef]

98. FORA. Green Business Models in the Nordic Region: A Key to Promote Sustainable Growth; FORA: Copenhagen, Denmark, 2010. Available online: http://www.motiva.fi/files/4878/Greenpaper_Green_Business_Models_in_the_Nordic_Region_A_Key_to_ Promote_Sustainable_Growth.pdf (accessed on 26 October 2021). 